DIASPORIC MOBILIZATION AND POST-WAR UPLIFT: AN INQUIRY INTO THE GLOBAL SRI LANKAN TAMIL DIASPORA'S INFLUENCE IN POST-WAR SRI LANKA

by

Sinthu Vimaladasan, BA, Wilfred Laurier University, 2017

\author{
A Major Research Paper \\ presented to Ryerson University \\ in partial fulfillment of the requirements for the degree of \\ Master of Arts \\ in the Program of \\ Immigration and Settlement Studies
}

Toronto, Ontario, Canada, 2018

(C) Sinthu Vimaladasan 2018 


\section{AUTHOR'S DECLARATION FOR ELECTRONIC SUBMISSION OF A MAJOR RESEARCH PAPER \\ (MRP)}

I hereby declare that I am the sole author of this Major Research Paper. This is a true copy of the MRP, including any required final revisions, as accepted by my examiners.

I authorize Ryerson University to lend this MRP to other institutions or individuals for the purpose of scholarly research.

I further authorize Ryerson University to reproduce this MRP by photocopying or by other means, in total or in part, at the request of other institutions or individuals for the purpose of scholarly research.

I understand that my MRP may be made electronically available to the public.

Sinthu Vimaladasan 


\title{
DIASPORIC MOBILIZATION AND POST-WAR UPLIFT: AN INQUIRY INTO THE GLOBAL SRI LANKAN TAMIL DIASPORA'S INFLUENCE IN POST-WAR SRI \\ LANKA
}

\author{
Sinthu Vimaladasan \\ Master of Arts, 2018 \\ Immigration and Settlement Studies \\ Ryerson University
}

\begin{abstract}
This study illustrates the changing nature of the global Sri Lankan Tamil diaspora; it's social, political and economic influence on Sri Lanka, and its participation in post-war resettlement and sustainable development initiatives. Moreover, it seeks to investigate if the perceptions of the diaspora are reflective of the ground realities in their homeland. This is evidenced by the accumulated data informed by key Tamil actors and organizations in Sri Lanka, Canada and England. Furthermore, this study reviews contemporary courses and conflicting opinions of diasporic engagement, and investigates the structural barriers that impede on positive peacebuilding. The results of this study suggest that such barriers frustrate diasporic mobilization, ultimately reducing the anticipated influence on the Sri Lankan state. Additionally, due to the digitized transnational space, ground realities are difficult to conceal; however, the level of involvement determines the depth of knowledge concerning the ground realities for the Tamil populace in Sri Lanka.
\end{abstract}

Key words: post-war, development, diaspora, Sri Lankan Tamils (SLT), militarization, identity 


\section{Acknowledgements}

First and foremost, I would like to thank my Amma (mother) Chanthira Vimaladasan, Appa (father) Vimaladasan Gnanapragasam and Thangachi (younger-sister) Vasuki Vimaladasan for endlessly and patiently supporting my educational endeavours throughout my life. Words cannot justly describe my gratitude and love for all the sacrifices you have made to see me succeed academically, shine professionally and grow personally. I could not have done it without you; I love and thank you endlessly.

I would like to thank my supervisor Dr. Tariq Amin-Khan for believing in my research, encouraging my research undertakings in Sri Lanka, and for providing focus to my colossal ideas. Your words of encouragement and constructive critique has truly helped me excel in my research and grow academically. I would also like to thank Dr. Sepali Guruge for taking the time to be my second reader, as your critical feedback has contributed to the successful completion of my work.

Thank you to my Mama (uncle) Arivuarasan Rasan Kandappu for supporting me during the recruitment stage of this study while in Sri Lanka. Your continuous words of wisdom, unrelenting willingness to help, and unceasing encouragement has shown me love and family have no borders.

Thank you to my remarkable 2017/2018 ISS cohort for being exceedingly supportive and encouraging throughout the year; a special thanks to Amelia Galizia for your kindness and positive energy. I would also like to recognize my incredible friends Sharyne Renée Williams, Arina Miriam Louis, and Anett Sukanya Selvarajah for their immeasurable support, love and care. In particular, thank you Rawan Shannak, for your "tough love", continued cheers and tears of joy, incalculable cups of coffee, boundless laughter and immense patience. I am extremely thankful and blessed to have you all in my life.

Last, but not least, I want to thank the influential and forward-thinking leaders of our global Tamil community, who I got the humbling opportunity to speak with. Your work within our community has been fostering change, producing resilience and building bridges between our homeland and the diaspora. I would like to thank you all for taking the time to be a part of this study, as it would not have been possible without your support.

“கற்க கசடறக் கற்பவை கற்றபின் நிற்க அதற்குத் தக”

"KaiRka kasadaRak kaiRpavai katrapin niRka adhaRkuth thaga"

"Learn well what should be learnt, and let your conduct be worthy of your learning"

திருவள்ளுவர் (Thiruvalluvar) 


\section{Dedication}

I would like to dedicate this paper to my father's twin brother and my Periyappa (uncle) Amaladasan Gnanapragasam who valiantly perished in 1985 after being targeted for helping school children find refuge during the warfare in Kayts, Sri Lanka. I am told that my creative perceptiveness and humanitarian interests are reminiscent of your character, and I am truly honoured to call you my uncle.

I would also like to dedicate this paper to mother's sister and my Chithi (aunt) Selvarani Kala Paraloganathan who departed during the last and most brutal phase of the war in Sri Lanka. Her unconditional love, beautiful smile, unrelenting resilience and compassionate energy will forever be ingrained in my memory.

Amalan Periyappa and Kala Chithi have inspired my academic endeavours in various ways, taught me about my ancestral roots and have helped me understand my own Tamil identity. Thank you for your sacrifices; your selfless, resilient and hopeful nature, and for bringing people happiness in the midst of adversity. 


\section{TABLE OF CONTENTS}

AUTHOR'S DECLARATION

ii

ABSTRACT

ACKNOWLEDGEMENTS

DEDICATION

LIST OF APPENDICES

\section{CHAPTER 1}

$\begin{array}{lr}\text { Positionality } & \mathbf{1} \\ \text { Introduction } & \mathbf{1} \\ \text { Research Questions } & \mathbf{3} \\ \text { Literature Review } & \mathbf{4} \\ \text { Conceptualizations and Operationalization of Key Terms } & 4 \\ \quad \text { Diasporas and Transnationalism } & 4 \\ \text { The Tamil Consciousness } & 5 \\ \text { Ethno-nationalism } & 6 \\ \text { Post-war vs. Post-conflict: When does war end and peace start? } & 7 \\ \text { Post-war Resettlement } & 7 \\ \text { Sustainable Development } & 7 \\ \text { Theoretical Framework } & 8 \\ \text { Positive Peacebuilding } & 9 \\ \text { Sinhala Buddhist hegemony } & 10 \\ \text { Militarization } & 10 \\ \text { Transnationalism } & 11 \\ \text { Social Identity Theory } & 12\end{array}$

\section{CHAPTER 2}

$\begin{array}{ll}\text { Brief Historical and Contemporary Overview of Sri Lanka } & 13\end{array}$

$\begin{array}{ll}\text { Overview of Post-War Conditions of Sri Lanka } & 14\end{array}$

Post-War Fiscal Reforms $\quad 15$

$\begin{array}{ll}\text { Post-War Infrastructure and Urban Development } & 15\end{array}$

Post-War Political Reform and Human Rights Abuses 16

\section{CHAPTER 3}

Exploring the Diaspora's Response to Homeland Affairs $\quad 18$

Major Methods of Diasporic Mobilization Prior to $2009 \quad 19$

$\begin{array}{ll}\text { Civil Administrative Structure of the LTTE } & 20\end{array}$

LTTE Funding $\quad 21$

2008-2009 Demonstrations $\quad 22$

Post-War Methods of Mobilization $\quad 23$

The Diaspora's Attachment to the Homeland 25

The Reconfiguration of the Tamil Identity for Diasporic Tamils 26 


\section{CHAPTER 4}

Methodology 29

Research Design $\quad 29$

Sampling Design 31

Interviews $\quad 32$

Research Participants and Affiliated Organizations 33

$\begin{array}{ll}\text { Disclosure } & 37\end{array}$

$\begin{array}{ll}\text { Limitations } & 38\end{array}$

\section{CHAPTER 5}

Findings \& Analysis $\quad 40$

The Militarization of Post-War Sri Lanka $\quad 40$

Militarized nationalism $\quad 44$

Militarized masculinity 46

Militarization as a Barrier to Diasporic Engagement

Personal Observations $\quad 48$

Solutions to Militarization 49

Recommendations on Mobilizing the Diaspora for Post-War SLT Uplift 51

Civil Society Capacity-Building $\quad 51$

Establishing Mentorship Programs 52

The Maintenance of International Partnerships $\quad 53$

Acquisition of Social Capital $\quad 55$

$\begin{array}{ll}\text { The Digital Tamil Diaspora } & 57\end{array}$

$\begin{array}{ll}\text { The Interpretations of Memory } & 60\end{array}$

The Divergence in Structure and State Responsibility 63

How Displacement Deters Positive Peace $\quad 67$

Intersectional Perspectives to Development and Diasporic Engagement 71

\section{CHAPTER 6}

Discussion $\quad 72$

$\begin{array}{ll}\text { Conclusion } & 75\end{array}$

$\begin{array}{ll}\text { Appendix } & 78\end{array}$

$\begin{array}{lr}\text { References } & 84\end{array}$ 


\section{List of Appendices}

Appendix: Consent Agreement 


\section{POSITIONALITY}

I declare that I am of Sri Lankan Tamil (SLT) background and a member of the SLT diasporic community in Canada. In order to be a research participant in this study, a strict inclusion criterion was appointed to preserve the Tamil voice; all research participants must identify as Sri Lankan Tamil. In fact, this study maintains the perspectives of the SLT diasporic community as well as the Tamil community in Sri Lanka. That being said, a Tamil-centric focus will be upheld throughout this paper to investigate the shifting nature of the global SLT diaspora and explore the transnational community's influence on and participation in sustainable post-war resettlement endeavours - informed by Tamil key actors and organizations. Moreover, my positionality is further addressed in the Methodology section of this paper under the Disclosure subsection.

\section{INTRODUCTION}

Situated off the southeast coast of India, the small island of Sri Lanka has been engulfed in conflict since the time of its formation. However, May $19^{\text {th }}, 2009$ officially marked the end of the nearly three-decade war and the fall of the Liberation Tigers of Tamil Eelam (LTTE); an operation orchestrated by Sri Lankan military forces (O’Neill, 2015, p. 125). Commencing as a 'shadow-war', violent hostilities gradually swept through the island for approximately 26 years (Vimalarajah \& Cheran, 2010), resulting from the island's colonial legacy, in addition to the ethnic tensions and political rancor between the Sinhala majority and the Tamil minority. As result of this, the native land was subjected to an ethno-nationalist war, which was waged between the Sri Lankan government and the LTTE that lasted for decades. Although there are varying opinions about the LTTE and their fight for an autonomous Tamil state, the LTTE's 
position was intended to serve as the voice for the silenced Tamil minority group on the small island of Sri Lanka. The LTTE was a recognized group that stood up for the rights and livelihoods of Tamils, while the international community as well as the United Nations remained dormant throughout the protracted ethno-nationalist war. Former President of Sri Lanka, Mahinda Rajapaksa failed to address the root causes and consequences of the ethno-nationalist war. Instead, he advocated for the prioritization of an ethno-nationalist agenda for peace development (Harrison, 2013; Satkunanathan, 2016; Wayland, 2004). Despite the acknowledged culmination of the war, existing literature and news outlets suggest that the Tamil community in Sri Lanka feels as though the systemic and deliberate destruction of the Tamil consciousness continues to be a pressing reality. As a result, the last phase of the military combat was a "war without witness", claiming well over 40,000 Tamil civilians and arbitrarily detaining more than 250,000 Tamil non-combatants in camps, due to obscure and unjustified allegations (Vimalarajah \& Cheran, 2010, p. 5).

This study will explore the changing nature of the global SLT diaspora and its involvement in post-war resettlement and sustainable development efforts, involving accumulated data informed by key Tamil actors and organizations. Known for their fervent political demonstrations on an international scale, the SLT diaspora has engaged with homeland politics through a new method of mobilization that is in fact a multiplicity of political, social and economic modes of engagement, activism, and advocacy that address diverse areas of development. Furthermore, this paper will examine post-war resettlement initiatives by the SLT diaspora that hope to cultivate sustainable development in the Northern and Eastern Provinces in Sri Lanka, and ultimately, contribute to a larger and imagined positive peacebuilding progression for the conflict-stricken island. In order to establish a truly positive peacebuilding process, this 
study will discover the structural dimensions that reinforce this culture of violence and ethnopolitical unrest. By acknowledging the history of the state, and recognizing how Tamils continue to feel exploited and abused, it will allow for the establishment of sustainable structures to support positive peacebuilding and the post-war resettlement of Tamils in Sri Lanka. To understand the intersectional nature of this study, this paper will be dissected into six parts, which will begin with a comprehensive preface discussing key concepts and the theoretical framework, as part of the literature review to provide more structure. This will be followed by a very basic background understanding of Sri Lankan history and a contemporary overview of state affairs to ensure contextual knowledge for the upcoming sections. Subsequently, the global SLT diaspora's response and engagement patterns pre- and post-2009 will be critically examined. It is imperative to note that the Methodology section is situated after the above sections to ensure that there is enough knowledge on the topic at hand prior to delving into the technical aspects of this study. Following this, my research findings will be examined, and emerging themes will be explored, which will bring this small-scale study about diasporic engagement in homeland affairs to a close.

\section{RESEARCH QUESTION}

In the context of Sri Lanka, it is undeniable that Tamil diasporic members and organizations have been engaging in several activities that can potentially alter the social, economic and even political processes of the homeland; however, it is the beneficial nature of this participation that is under examination. I have proposed a two-fold research question to examine the influence of SLT Tamil diasporic mobilization in the homeland of Sri Lanka, 
thereby guiding this study. The inquiry is as follows: (1) Is the perception of the global Sri Lankan Tamil diaspora reflective of the present ground realities in their homeland?; and (2) Can the Tamil diaspora influence the Sri Lankan state with regards to social, economic and political outcomes favourable to Tamil civilians in Sri Lanka while assisting the latter with postwar resettlement? Although the fall of the LTTE dramatically reduced the Tamil diaspora's involvement in homeland affairs, the post-war diasporic methods of mobilization that are explored in this paper can play a pivotal role in the island's future.

\section{LITERATURE REVIEW}

\section{Conceptualization and Operationalization of Key Terms}

\section{Diasporas and Transnationalism}

The term "diaspora" derives from the Greek meaning "to sow over or scatter" (Vertovec, 2005, p. 1). To understand homeland-diaspora politics, this study will draw on a combination of Wayland's (2004) classification, as well as Cheran's (2007) interpretation of Stuart Hall's definition of a diaspora. According to Wayland (2004), a diaspora is the dispersion of persons that collectively create and reside within transnational communities outside the homeland (p. 408). Stuart Hall goes further in describing the diaspora as a hybrid space for identity formation produced and shaped by displacement and cultural shifts; ultimately recognizing the evolving nature of these transnational communities (Cheran, 2007). Hall's definition acknowledges the multiple "ways of belonging" and the various ways of incorporating these diasporic hybrid identities into the "home" and "host" countries (Cheran, 2007, p. 130).

Transnationalism, on the other hand, is referred to as the communal identities that extend outside the margins of the native state, such as to create diasporas (Wayland, 2004, p. 406). As 
discussed by Wayland (2004), the uniqueness of the Tamil diaspora is that its mere existence, and extra-terrestrial but rapid global formation, is largely a result of ethno-nationalist conflict and fear of persecution in the homeland, as opposed to the objective to fulfill economic needs or the desire to pursue a life abroad (p. 408). That said, Thurairajah (2017) identifies the "coherent narrative of the 'original' homeland" (p. 116) as the one dimension that differentiates a diasporic community from a transnational community. By this demarcation, the SLT diaspora has a dependency on the homeland, with an inclination towards emotional attachment to the roots and cultural elements connected to Sri Lanka (Thurairajah, 2017). It should be clarified that any mention of the homeland refers to Sri Lanka, whether the mentioned connotative perception of the homeland is "real" or "imagined".

\section{The Tamil Consciousness}

Cohen (1997) states that a powerful "ethnic group consciousness" is one that is continued over a protracted time-period and is founded on a level of distinctiveness, shared history, diffusion of a common cultural - and even religious inheritance - as well as a collective belief in a similar destiny (p. 17). Tamil consciousness is in line with Cohen's (1997) description. This ingroup identification is seen as a communal resource that produces collective political activity due to the shared attachment associated with the ethnic group (Smith, 2013). The Tamil consciousness is then a politicized set of ideological beliefs and an awareness of dwelling in a Tamil hybrid space or existence that exceeds boundaries, but fosters support for "collective action" (Smith, 2013, p. 201), strengthens group pride and generates a politically efficient method of approaching group issues (Smith, 2013; Cohen, 1997). Smith (2013) believes that simply "acquiring a group identity and a sense of common fate is therefore just the first step toward a fully developed group consciousness" (p. 201). It is then the collectiveness and 
closeness illustrated by members within that ethnic community that partly determines the strength and productivity of that group's ability to mobilize and invoke political activism. As exemplified by the Tamil consciousness, ethnic group consciousness may exist in consequence of the group's experiences and/or perceptions of discrimination within Sri Lanka or the hostland (Smith, 2013).

\section{Ethno-nationalism}

Ethno-nationalism remains highly-debated and continuously conceptualized in various ways and disciplines. According to Dyrstad (2012), ethno-nationalism is homogenous in its approach; therefore, "loyalty to the group is stronger than loyalty to the state" (p. 818). Ethnonationalism seeks exclusivity and is established on the premise of a shared descent. Furthermore, this collectiveness will allow the ethnic group to politically mobilize for various causes from self-determination to statehood. In the case of Sri Lanka, the Rajapaksa regime adopted an ethnonationalist agenda that focused on the Sinhalization of the island, orchestrated through the calculated extermination of the Tamil populace and culture in its entirety (Harrison, 2013; Satkunanathan, 2016; Wayland, 2004). There is a clear distinction between an ethnic movement and an ethno-nationalist movement. In an ethnic movement, the objective of an ethno-politicized elite is to obtain some benefits within the respective state, whilst nationalists specifically seek to establish or maintain their own state (Singh, 2008). Singh (2008) finds ethno-nationalism to function as a "double-edged sword" (p. 493); from the perspective of the state, ethnic minorities become a problem due to their progressive and rather confident assertion of confrontational political positions, collective identity, culture, language, religion and other identity markers (p. 494). On the other hand, the state interferes and discriminates against ethnic minorities because it disagrees with the ethnic group's political ambitions (Singh, 2008). 


\section{Post-war vs. Post-conflict: When does war end and peace start?}

There is a blurred line between the culmination of war and the ignition of peace, as it is a concept that continues to be theorized. Nonetheless, one reality remains certain, Sri Lanka has been faced with ethno-nationalist and religious tensions and bloodshed for decades, and the capacity and means for post-war repair in the form of peacebuilding remains ambiguously navigated and poorly implemented. In this study, Sri Lanka will be referred to as a post-war society instead of a post-conflict society because, although the war has formally come to an end, there continues to be covert and explicit conflict within the borders of the nation-state. Moreover, the post-war period refers to all activities from 2009 and onwards.

\section{Post-war Resettlement}

Post-war resettlement is a growth process that occurs after a human-made disaster that often leaves behind inequality and enduring social, economic, institutional and environmental impacts onto the state (UN-Habitat, 2013). The purpose of post-war resettlement is to merge peace and security of those affected by wars through the establishment of sustainable socioeconomic structures that mitigate against future conflicts (UN-Habitat, 2013). In the case of Sri Lanka, this growth process includes addressing the continued displacement of Tamil civilians on the island, the occupation of land by military forces, the demolition of homes upon the release of the land, and supposed resettlement of these territories, as well as the overall destruction of the Tamil community's livelihood within the island.

\section{Sustainable Development}

Sustainable development in this context is contingent upon finding long-term solutions for the Sri Lankan state that are resourceful and can generate a knowledge-based economy. According to the United Nations Development Programme (2018a), to procure sustainable 
development, there must be "an enabling environment for access to opportunities, focusing on the most vulnerable and excluded population groups." Moreover, sustainability should include action from economic, social and environmental standpoints (UNDP, 2018a). In addition to the addressed avenues of economic, social, and environmental factors covered in this formula for sustainable development, the writer wishes to acknowledge the crucial role that political stability contributes in the grand scheme of fulfilling and maintaining the needs of the Tamil population in Sri Lanka. Although all may be applicable, this research study will broadly touch upon how the state can achieve these four UN Sustainable Development Goals (SDGs):

8. Promote sustained, inclusive and sustainable economic growth, full and productive employment and decent work for all;

9. Build resilient infrastructure, promote inclusive and sustainable industrialization and foster innovation;

16. Promote peaceful and inclusive societies for sustainable development, provide access to justice for all and build effective, accountable and inclusive institutions at all levels; 17. Strengthen the means of implementation and revitalize the global partnership for sustainable development (United Nations Development Programme, 2018b).

\section{Theoretical Framework}

Before delving into the research, the theoretical framework must be appropriately integrated to provide structural clarity. Grant \& Osanloo (2014) allegorically refer to a theoretical framework as a "blueprint" (p. 12). Thus, much like the blueprint of a home guides the manifestation of operational construction; Grant \& Osanloo (2014) advise us that the appropriate theoretical framework will serve as such a blueprint; providing vision and structure for the research. The theoretical framework is integral to the literature review section of this paper and will serve as a guide for the entire research study process, while assisting in the conceptualization and organization of relevant literature in a broader context. Moreover, a comprehensive assessment of existing literature regarding homeland-diaspora politics, particularly on the SLT transnational space, has also been consulted to further contextualize the 
study. Notably, this paper will employ a multi-theoretical approach to address the intersectional characteristics of the global SLT diaspora, its ethnic group consciousness and its relations to the homeland. The concepts that will be employed in developing this paper's theoretical framework include positive peace-building; a micro-concept emerging from the extensive peace and conflict studies approach, Sinhala-Buddhist hegemony, militarization, as well as transnationalism and social identity theory.

\section{Positive Peacebuilding}

This study will utilize the positive peacebuilding approach to analyze the way a state can transition from negative to positive peace using Price's (2010) definitions. According to Price (2010), negative peace is the mere "absence of physical armed conflict" (p. 530), whereas positive peace is a much more elaborate concept. Positive peace encompasses more than merely ending physical warfare, it considers the structural dimensions that work to reinforce a culture of violence or reinstate ethnic, religious and political unrest in society, with the ultimate goal of fostering sustainable solutions to ending armed conflict. Positive peacebuilding involves the act of identifying the barriers that deter positive peace from ensuing, while focusing on the supporting structures that strengthen positive peace with intention to avoid returning to warfare (Price, 2010).

In the case of Sri Lanka, the barriers that deter the positive-peacebuilding process include Sinhala-Buddhist hegemony and the militarization of the state; the latter is classified into two divisions, the first being militarized nationalism and the second being militarized masculinity. Additionally, Sinhala-Buddhist hegemony and militarization are in fact the structural components that not only hold institutional power, but also reinforce ethnic, religious and political unrest in Sri Lanka. Furthermore, these two concepts collectively generate fear within 
the Tamil community in Sri Lanka, as they control Tamil diasporic activities and Tamil engagement in Sri Lankan civil affairs. To understand the post-war society of Sri Lanka, it is imperative to investigate these influential factors.

\section{Sinhala Buddhist hegemony}

Sinhala-Buddhist hegemony concerns the emergence of the Buddhist political elite in Sri Lanka that had turned a "religiously plural society into one defined by religious hegemony" (Woods, 2012, p. 203). In this paper, religious hegemony is defined as the institutionalized, systematic and pervasive dominance of set religious and cultural values that yield social, political and economic power within a society (Woods, 2012). In the case of Sri Lanka, this Buddhist hegemony is a production of Sinhala nationalism extended throughout the state. Although the Sinhala majoritarianism, following Sri Lanka’s independence in 1948, commissioned the apparent ethnic, religious and political identities and differences, the acclaimed "hegemonization of Sinhala nationalism" began between the 1950s and 1970s (Rampton, 2011, p. 259). Moreover, the Sinhala Only policy in 1956, the disdain against the Tamil language in educational and vocational spaces, as well as the denial of access to the English language due to its elite status, all further institutionalized Sinhala nationalism into the structural dimensions of the state (Rampton, 2011). Therefore, Sinhala Buddhist hegemony is exemplified by dogmatism, suppression and intolerance to difference, more specifically, of minority groups in Sri Lanka (Woods, 2012).

\section{Militarization}

When attempting to find an operational definition for militarization, there was a common classification suggesting that militarization is by and large when a state organizes itself for war and violence. Since the conclusion of the war, Sri Lanka has alternatively adopted the 
securitization approach in place of the human rights approach, in attempt to justify and naturalize the overwhelming presence of Sri Lankan armed forces in civil society. Militarization as a theory seeks to investigate the institutional and ideological naturalization of the armed forces in Sri Lanka, how their presence influences and shapes Sri Lankan civilian affairs in the post-war context, as well as how their post-war presence responds to the Tamil diaspora's involvement in homeland politics. Subsequently, militarized nationalism reflects the level of militarization of the state; therefore, the state's national identity and society has increased military involvement in civilian affairs, while also glorifying Sri Lankan armed forces and their unyielding power (Seoighe, 2016b). Militarized masculinity is then strengthened by the day-to-day operations of the heightened militarization of the state. Furthermore, it also emphasizes a single form of masculinity against which military camaraderie and combativeness is produced, and violence is seen as an accepted and routine way of imposing dominance (Tapscott, 2018, p. 5121; Bjarnegård \& Melander, 2011, p. 142).

\section{Transnationalism}

While globalization emerges as an important and leading discourse paired with current global migration trends, transnationalism has expectedly received an immense amount of attention (Vimalarajah \& Cheran, 2010). Transnationalism is essential to understanding the diffusion of social and political processes beyond judicial and territorial boundaries. The traditionally understood classification of transnationalism includes the transfer or movement of fiscal resources and goods receding economic and social state boundaries. In addition to this definition, transnationalism is also people-centric and focuses on the networks they form as well as the transmission of ideas (Vimalarajah \& Cheran, 2010; Cheran, 2007). This creates a level of transgressive hybridity amongst the influenced spaces and networks that surpass and challenge traditional transnational categorizations (Clavin, 2005). This research study will adopt Cheran's 
(2007) definition of the Tamil transnational community. Both the "hostland" and the "homeland" must be observed and recognized in the same hybrid space of transnational and ethnic identities (Cheran, 2007, p. 131). By doing this, Tamils who reside within the diaspora as well as Tamils within the homeland should be developed as one in a socioeconomic and political field that exceeds physical state borders, conventional cultural margins, and territorial or caste-based rivalries (Cheran, 2007).

\section{Social Identity Theory}

In addition to transnationalism, ethnic membership into the Tamil diaspora as a factor of both political activism and collective mobilization will be explored through the theoretical lens of social identity theory. Debatably, the traditional understanding of social identity theory presents a very fixed identity that lacks fluidity (Huddy, 2001). Removing the fixed aspect of the definition, this study will assume the position of Stets \& Burke (2000), in that social identity is the composition of a group with persons whom share social identifications and identify themselves as part of the same social grouping. This identification or membership is not necessarily exclusive to a single identified group, which is where flexibility of identity is allowed; however, the process of self-categorization does take place. For example, Tamil diasporic members living in Canada can identify as part of the Tamil community but can also classify themselves as being part of the Canadian society. There is an obvious in-group and outgroup partition that exists, possibly due to the experiences of discrimination or segregational attitudes bestowed upon ethnic minorities by dominant society (Stets \& Burke, 2000). Furthermore, many of these labels and categories arguably exist within minority groups to construct a protective shield and/or safe space. Such a space may allow members to feel a sense 
of belonging in a foreign environment, and/or allow members to freely confide in one another regarding a shared experience devoid of the overwhelming presence of the out-group.

\section{BRIEF HISTORICAL \& CONTEMPORARY OVERVIEW OF SRI LANKA}

To grasp the complex dimensions of this ethno-nationalist conflict in Sri Lanka, the history must be explored. Situated off the coast of India, rests the tropical island of Sri Lanka, a land covering 65,000 square kilometers (km) of the earth's surface (BBC, 2017; Amarasingam, Naganathan \& Hyndman, 2016, p. 124-125). The nation has a rich history of bloodshed and battle that originates back many centuries in time. Before the national conflict overtook the country's political climate, the island fell under Portuguese, Dutch and British control; however, in more recent history, the state has been scarred by a long and bloody war driven by ethnic tensions between the Tamil minority and Sinhala majority. With a population of over 20 million, the Sinhalese are the predominant ethnic group, making up $74 \%$ of the populace and mostly identify as Buddhists. In contrast, Sri Lankan Tamils comprise a meager 12\% and Indian Tamils make up an even lower percentage of $4 \%$ of the SLT population. Theologically, these two ethnic groups identify as Hindu or Christian, with the former religion being the most prevalent. Muslims, who are largely Tamil, are regarded as their own category; making up 9\% of the population. It is imperative to note that Veddhas, whom are the indigenous peoples of the land as well as Burghers, whom are the descendants of European colonizers, occupy a small fraction of the populace as well (Amarasingam, 2015, p. 15). A pivotal moment that shifted the fate of the state and provoked the hostility between both groups was owing to the passing of the 1956 Sinhala Only Act when the Sinhalese government replaced English with Sinhala as the island's official language. This Act provided legal authority to oust Tamils from civil service positions 
and denied the minority group equal access to education, health care and land ownership; thus, deliberately driving the Tamil populace into an impoverished condition within their own state (Sandercock, Dickout \& Winkler, 2004, p. 11-12). In the 1970s, neo-liberal policy implementations as part of the economic restructuring agenda of the state further segregated and shoved Tamils into destitute margins of society. All these events led to the polarization of the Sri Lankan population in the 1980s; foreshadowing the eventual escalation of conflict breeding unrestrained violence beginning in 1983. At this point, Tamils were internally displaced, missing, or dead (Sandercock et al., 2004, p. 11-12). In July of 1983, also referred to as Black July, the LTTE launched a lethal attack, killing numerous members of the Sri Lankan army. As a means of retribution, the Sinhalese government permitted and wholeheartedly supported the Sri Lankan Army's (SLA) operations of decimation against Tamils in Colombo - the capital city of the country; resulting in bloodshed that uncontrollably cascaded into neighbouring regions (Amarasingam et al., 2016, p. 125). Although there were peace talks in 1985, followed by a Ceasefire Agreement in 2002, the conflict continued until May $18^{\text {th }}, 2009$ when the SLA took down the LTTE in its entirety. Created in 1976, the LTTE was established to institute a recognized autonomous Tamil state - Tamil Eelam - specifically within the Northern and Eastern parts of Sri Lanka - regions in which comprised the most Tamils. The United Nations estimates that approximately 70,000 civilians were killed in the turmoil; yet, this number fails to account for the vast majority of unreported deaths that have gone unquestioned throughout the conflict as well as missing persons of the state (Amarasingam et al., 2016, p. 125).

\section{Overview of Post-War Conditions in Sri Lanka}

Sri Lanka is a nation that that has been engulfed in conflict for a quarter of a century and now, the Sri Lankan government has the historic opportunity to mend the broken state. For repair 
to ensue, Sri Lanka needs to invest into resources that will make infrastructural, economic, and political strides of growth; ultimately bringing about social change to the divided nation. Although there may be economic and infrastructural reform within the island in order to increase competitiveness and produce a rather steady economy, unfortunately, the Tamil populace has not been able to reap the benefits of such developments due to years of violent hostilities, displacement, and discriminatory treatment.

\section{Post-War Fiscal Reforms}

According to the World Bank (2018), the Sri Lankan economy has upheld a strong growth rate in the past nine years since the conclusion of the war. In the post-war era, the economy has begun its shift from a rural-based economy to a more urbanized market (World Bank, 2018). Additionally, there have been several commitments made regarding peace, reconciliation and various developments; however, the decades of conflict continue to dictate the state's sociopolitical framework (Herath, 2015; World Bank, 2018). Unfortunately, there has been a lack of progression with such commitments in the last three years. The Sri Lankan government, along with the support of the World Bank, wish to implement economic reforms by improving "public financial management, increase public and private investments, address infrastructure constraints and improve competitiveness" (World Bank, 2018). Though these reforms hope to ensure sustainable development if wholly executed, many of these economic development plans have been deferred due to the obstacles presented by the political instability within the state (World Bank, 2018).

\section{Post-War Infrastructure and Urban Development}

Sarvananthan's (2016) review of Sri Lanka's post-war economic development in the conflict-affected areas, most of the developments throughout the country adopted a "blanket 
approach" that paid no attention to the specific needs of members within distinguished communities (p. 574). There have been large-scale public ventures in infrastructural reconstruction such as highways, roads, and airports, but a lack of focus on rebuilding livelihoods for those affected by the war. This blind relief process orchestrated by the state and the private sector yielded high costs and were not as productive to the economic development of the state as anticipated (Sarvananthan, 2016). These economic reforms were expected to produce employment and income, but the results have demonstrated otherwise. Sarvananthan (2016) articulates how specific circumstances and priorities were not considered in the process of pursuing capital concentrated investment. He states that within the Mannar and Mullativu districts located in the Northern Province, there are large cattle populations, yet the state as well as public and private investors did not undertake any dairy development projects within these areas - even though the demand was high (Sarvananthan, 2016, p. 574). In addition to this, many developments lacked cost-efficiency such as exploring alternative modes of transport- such as rail and water transportation systems; resources that could have been valuable in other areas of economic growth.

\section{Post-War Political Reform and Human Rights Abuses}

For the government to regain the trust of the Tamil community in Sri Lanka and successfully produce any economic and social progression, the state must take responsibility for its past abuses, especially for the atrocities committed during the final stages of the war. Instead, the Sri Lankan government is denying all allegations of human rights violations committed during the war, and officials insist that they are working towards reconciliation efforts (BBC, 2015) Such claimed efforts include the rebuilding of Sri Lanka's Northern region which was destroyed during the warfare (BBC, 2015). The 2011 Report of the Secretary-General's Panel of 
Experts on Accountability in Sri Lanka revealed that between September 2008 and May 2009, the Sri Lankan Army accelerated its military campaign, with concentrated shelling within the No Fire Zones. These specified zones housed the United Nations hub, food distribution lines, frontline hospitals, and the International Committee of the Red Cross (ICRC) (2018) ships that were coming to assist the wounded from the beaches (p. 4). In January 2015, Sri Lankan civilians and Tamil diasporas around the world hoped that they would see diplomatic change as now Prime Minister (PM) Maithripala Sirisena from the Sri Lankan Freedom Party took over the seat of the former long-standing PM of Sri Lanka, Mahinda Rajapaksa. Unfortunately, the Sirisena administration has yet to uphold all reformist promises that gave him the votes to succeed in the 2015 election (Human Rights Watch, 2017).

In attempt to take accountability for past abuses, the United Nations Human Rights Council adopted a consensus resolution in October 2015 to implement various human rights reforms and transitional justice demands, aimed to prevent the resurfacing of ethnic tensions and resultant conflict within the state. Under the resolution, Sri Lanka has pledged to establish four transitional justice instruments: the founding of a special court that successfully integrates "international judges, prosecutors, lawyers and investigators with an independent investigative and prosecuting body" (Human Rights Watch, 2017). Secondly, the consensus resolution has specifically instructed an office be mandated to undertake cases on missing and disappeared persons. The third transitional justice measure is to be a "truth-telling mechanism," and the final mechanism is to be constructed to ensure non-recurrence as well as reparations (Human Rights Watch, 2017). The government has failed to effectively employ these recommendations to improve the deprived human rights condition of the state (Human Rights Watch, 2017). In February 2017, the United Nations Human Rights Council (2017) released the Report of the 
Office of the United Nations High Commissioner for Human Rights on Sri Lanka. The report addressed the importance of establishing trustworthy transitional justice processes to provide victims with the necessary resources for recovery, to strengthen society and to address grievances (Human Rights Council, 2017, p. 10). Nonetheless, police abuse, excessive use of force and torture continue to persist in Sri Lanka. Torture has been routinely used as a method of interrogation and investigation, which has played a role in the past abuses and current impoverished conditions of the state (Humans Rights Council, 2017, p. 13). Militarization will be further discussed in a later chapter; however, it is imperative to note that many calls have been made by various international bodies to demilitarize the Northern and Eastern provinces of Sri Lanka. Unfortunately, the Sri Lankan government has failed to address this concern, resulting in the repression and abuse of basic human rights of Tamil civilians living in the mentioned waraffected districts (ACPR \& PEARL, 2017).

\section{EXPLORING THE DIASPORA'S RESPONSE TO HOMELAND AFFAIRS}

As the conditions of the island continue to shift due to the instability presented by the colonial, historical and contemporary political climates, the involvement of the global Tamil diaspora has evolved from the pre-2009 warfare period to the post-war era. This section will then explore the perceptions and influence of the Tamil diaspora on the social, economic and political conditions facing Tamils in the Sri Lankan state, in addition to the acclimatization of the Tamil identity throughout the changing conditions of their homeland. Resultantly, the diasporic Tamil identity and the global Tamil diaspora's modes of mobilization are continuously adapting due to their deeply rooted attachment to the homeland, and the post-war environment of the Sri Lankan state. Prior to 2009, the Tamil diaspora shaped the Sri Lankan political landscape through its 
fiscal and ideological support towards the fight for Tamil Eelam - an independent Tamil state; however, now, there is a rise in support through associations, non-profit organizations and research institutions, in attempt to sustain the Tamil consciousness. Thus far, given the existing literature, there seems to be a gap between what is perceived to be a ground reality, and thus, a ground need, among the Tamil diaspora and the Tamil community in Sri Lanka. Through the informed findings by key actors, this research study will be analyzing the diaspora's response to the shifting conditions of the Sri Lankan state as well as their ability to influence the social, political and economic climate of the country's post-war environment. Furthermore, this study will not only review current diasporic engagement mechanisms, but also acknowledge the conflicting opinions between the global SLT diaspora and the Tamil community in Sri Lanka.

\section{Major Methods of Diasporic Mobilization Prior to 2009}

Although the diasporic and homeland conditions for determining identity are vastly different, the shared nature of the Tamil identity prescribes a responsibility for Tamil populations to both protect and defend their Tamil brethren, and to prevent the extinction of the Tamil heritage and language as attempted by the Sinhala majority government (Thurairajah, 2017). This chapter does not intend on discussing the highly politicized perspectives and arguments against or for the labeling of the Liberation Tigers of Tamil Eelam (LTTE), also known as "Tamil Tigers", as freedom fighters or as a terrorist organization. Rather, this section seeks to explore the civil organizational composition of the LTTE and the Tamil diaspora's role in the ethno-nationalist war prior to 2009; with the aim of providing a better understanding of the post-war participation of the global Tamil diaspora today. The high level of engagement prior to the fall of the LTTE as well as the global SLT diasporic community's ability to mobilize during the 2008-2009 period illustrates the strength of the overall hybrid Tamil identity. Ethnic group 
consciousness such as the cemented Tamil consciousness that is constantly being shaped allows for the Tamil diasporic community to remain invested and attached to the homeland (Cohen, 1997). Due to this tie and sense of belonging within their "real" or "imagined" homeland, there exists an incentive or motivation to engage in the affairs of the state. Provided that this is the rationale, regardless of the methods of mobilization and intensity of involvement, there has constantly been an unrelenting presence of diasporic engagement in Sri Lanka. This presence is so important because by lobbying the governments of the host-country, urging the international community to act, and directly and actively engaging in homeland development activities, the diaspora has and arguably will be able to transform the circumstances of their homeland or at least bring about some level of change (Thurairajah, 2017).

\section{Civil Administrative Structure of the LTTE}

Evolving out of a student group in the 1970s and led by Vellupillai Prabhakaran, the LTTE eventually expanded into a large-scale military force that deployed thousands of fighters armed with heavy artillery, in addition to a massive naval force (O’Neil, 2015, p. 130). Controlling $70 \%$ of the North and East of Sri Lanka, the LTTE built a vast civil administrative structure that composed of a police force, judicial system as well as a humanitarian assistance division. The exalted level of control by the LTTE reached the plane in which the organization operated a taxation system in both LTTE-controlled areas and government-held areas. By the late 1990s, many scholars like Nadarajah \& Sriskandarajah (2005) described the administration as a "defacto state" (p. 89). According to Thiranagama (2014), the LTTE allegedly had offices in approximately 40 different countries with a Tamil diasporic presence (p. 268). Furthermore, Thiranagama (2014) discusses the channeling of LTTE funding through Tamil diaspora cultural events as a means of underground political lobbying. However, Nadarajah \& Sriskandarajah 
(2005) refute this with the argument that the intricate and intertwined nature of the civil administration, Tamil transnationalism and the unique Tamil diaspora that fled Sri Lanka, as result of the protracted conflict, distorted the diaspora's sociocultural and politicized use of foreign space of settlement and its political support for the LTTE. Consequently, many Tamil diasporic organizations such as World Tamil Association (WTA), NGO Tamil Rehabilitation Organization (TRO), World Tamil Movement (WTM), and the Federation of Associations of Canadian Tamils (FACT), have thus been alienated as "front organizations" of the LTTE (Thiranagama, 2014, p. 268; Nadarajah \& Sriskandarajah, 2005, p. 95).

\section{LTTE Funding}

Prior to 2009, Sri Lanka received the title of being one of the top twenty countries within the Global South to obtain a large amount of remittances from its diasporic communities. According to the World Bank, Sri Lanka received US \$1,056 million in remittances in 1999, which amounted to $6.9 \%$ of the GDP (Cheran, 2007, p. 131). During the period of the military combat, Sri Lankan Tamils from Canada and various states in Europe were able to gather extensive resources to support the motive of establishing an autonomous Tamil state, while also providing humanitarian assistance to Tamils affected in the conflict-affected areas in the North and East of Sri Lanka (Cheran, 2007, p. 131). Attributable to the Tamil diaspora's distinctive formation and migration flows into countries such as Canada, the United Kingdom, Australia, India, and various parts of Europe, the LTTE was able to extend its support system and fundraising networks outside the margins of the state (Nadarajah \& Sriskandarajah, 2005, p. 93); thus, designing the initial method of diasporic mobilization for the homeland. Annual private remittances between the diasporas and Sri Lanka have accounted for 5 percent of Sri Lanka's GDP, exceeding 1 billion USD since 1999 (Wayland, 2004, p. 421-422). On the other hand, 
remittances, especially from the Tamil diaspora in Canada have arguably been the chief source of LTTE funding in the past. Although the accuracy of this estimation is widely disputed, the Sri Lankan government claims that the Tigers overseas fundraised an annual average of $\$ 80$ million (Wayland, 2004, p. 421-422). There was an increased flow of remittances into the state during the conflict, which was specifically being received by the LTTE (Guribye \& Tharmalingam, 2017, p. 183).

\section{8-2009 Demonstrations}

2008 and 2009 were the years of extraordinary activism, showcasing a contemporary case of a resistance movement orchestrated by the global Tamil diaspora across national borders. As the cries of the Tamils in Sri Lanka were being forcibly silenced, while the international community took the position of the bystander, and the Rajapaksa administration attempted to annihilate the Tamil consciousness in its entirety, diasporic Tamil voices garnered worldwide attention by taking to the streets (CBC News, 2009). Second-generation Tamils, many of whom were members of Tamil Student Associations at post-secondary institutions, had a large role in the organization and success of the protests in Toronto and London (O’Neill, 2015).

Furthermore, this period was the final phase of the ethno-nationalist war and the Tamil community continued to protest to call on the international community to question the atrocities occurring in Sri Lanka and aid those suffering within the homeland. In Canada, Tamil protestors shut down one of the busiest highways in Toronto - the Gardiner Expressway - as a means of seeking international pressure to force a ceasefire in Sri Lanka, giving the rest of society no choice but to question why such events were taking place (O’Neill, 2015, p. 125). Unfortunately, the call was ignored. Ban Ki-Moon, the former Secretary-General of the United Nations stated that the UN failed to learn from past tragedies such as the Rwandan genocide. Ban Ki-Moon 
further acknowledged that the need for "political will" from the Security Council, a "leadership role of the Secretary-General," human rights competence of staff on the ground," as well as the "importance of bringing human rights information to bear" at UN headquarter deliberations were all forgotten efforts into the case of Sri Lanka (Human Rights Watch, 2012). With that said, the diasporic political engagement gave the Tamil community agency and empowerment, which they were incapable of practicing prior due to the fear of persecution within their homeland of Sri Lanka. Furthermore, May $18^{\text {th }}, 2009$, marked the fall of the LTTE and the death of Prabhakaran, orchestrated by Sri Lankan military operations. However, the involvement of the global Tamil diaspora in the 2009 protests perpetually shifted and altered the transnational project of Tamil nationalism and exemplified the strength of diasporas - even amid White spaces (O'Neill p. 125126).

\section{Post-War Methods of Diasporic Mobilization}

Since the fall of the LTTE, remittances from the global Tamil diaspora have remained at a considerably low level in recent years (Guribye \& Tharmalingam, 2017, p. 183). Additionally, the return mobility of diasporic Tamils to the homeland also facilitated the exchange of remittances; however, this remittance process created social tensions and social inequalities within the Northern Province, where much of the aid was being allocated in disproportion to other regions. The negative impact of these remittances was also seen in the Tamil civilians' considerable dependence on diaspora funding rather than self-reliance and social engagement (Guribye \& Tharmalingam, 2017, p. 184). Rather than individual remittances, the SLT diaspora started collectively transferring funds by working in partnership with school, village, and religious associations. This collective system has proven to be more effective and circumvented the chaos and tensions that individual remittances were producing within the state (Guribye \& 
Tharmalingam, 2017, p. 183). Furthermore, due to the formation of the Presidential Task Force for Resettlement, Development and Security in the Northern Province of Sri Lanka, there has been a lack of support by the diasporas and local partners. The Presidential Task Force is strictly controlled by the government and was established to resettle internally displaced persons, develop infrastructure, and restore social services of the Northern Province - an area that has been largely structurally destroyed and eradicated of almost all its resources as a result of the 26year-old conflict (Guribye \& Tharmalingam, 2017, p. 182). That being said, there was a strict requirement that forced all development organizations and relief agencies situated in the predominately Tamil and former-LTTE controlled regions to work alongside the Sri Lankan authorities. By the end of the war, many Tamil civilians lost trust in their government as was the case for global Tamil diasporas, making it much more difficult to attain the alliance of global networks (Guribye \& Tharmalingam, 2017).

Diasporas can play a pivotal role in the positive peacebuilding and post-conflict resettlement process. Although many Sri Lankan Tamils have settled outside the homeland, their return to Sri Lanka has resulted in the recirculation of capital and new knowledge that has played an instrumental role in the post-conflict development of local schools, hospitals and community centres in areas most affected by the warfare (Pande, 2017, p. 59). That said, current literature remains highly critical of the diaspora's activism, claiming that such activism is producing divergence between Tamil civilians in their homeland and diasporic Tamils, specifically through the process of implementing development aspirations (Guribye \& Tharmalingam, 2017; Pande, 2017; Thurairajah, 2017; Canagarajah, 2013). Much of the divergence is a result of the perceived "ultimate goal" of the Tamil diaspora, which is arguably found within the legacy of a separate Tamil state. In contrast, many Tamil civilians are exhausted by the decades of war that they have 
been subjected to; they are strained by and looking for immediate solutions to displacement and the disappearances of family members, in addition to employment and educational opportunities (Guribye \& Tharmalingam, 2017; Pande, 2017). Almost a decade later, between June $30^{\text {th }}$ and July $1^{\text {st }}$, the Tamil diaspora took to the streets, holding a succession of rallies across the globe in solidarity with protesting Tamil families of the disappeared (Tamil Guardian, 2018d). These demonstrations - that occurred in Canada, USA, Australia, England, Ireland, Germany and Switzerland - symbolize a major movement of solidarity and is in fact, the largest, united rally to date, orchestrated by the global Tamil diaspora since the 2008-2009 demonstrations. This major post-war era event will be further explored in the Analysis section of this paper.

\section{The Diaspora's Attachment to the Homeland}

The Tamil diasporic community occupies space within the "real" or "imagined" homeland, due to the fostered dependency between both contexts. According to Cohen (1997), not all transnational communities are diasporas; rather, it is the sustained and prolonged period between migration and diasporic formation that generates a strong ethno-national diaspora with prevailing communal networks. Resultantly, it is overtime that a strong ethnic group consciousness forms - such as the multigenerational Tamil consciousness - and it is through the historical dimensions and grievances of the diaspora's formation that produces such a space for consciousness development. Regardless of the varying political positions within the Tamil diaspora and homeland, there exists a strong attachment to the past and desire to mobilize to ensure the Tamil consciousness and Tamil struggle is carried on through generations. Ethnic identity, such as the Tamil identity itself, is not automatically a "subject of politics" (Singh, 2008, p. 493); but because it is being used as the premise for political action, the identity represents a conscious movement. Thurairajah (2017) draws on an old-age Tamil saying: 
'Tamilan endru sollada; thalai nimirnthu nillada.' With the use of male pronouns, this translates to: "Say that you are Tamil; stand with your head held high" (Thurairajah, 2017, p. 129). Unfortunately, the author of this phrase is unknown, but the saying exerts an honourable level of pride with regards to belonging within the cohesion of Tamil ethnic identity. Although this saying is globally known by many Tamil-speaking individuals, as addressed by Thurairajah (2017), this saying does not necessarily discuss "what it means to be Tamil" (p. 129). It is the shared distinctiveness and the emotional attachment of being a "Thamilizhar" - an identity that was and continues to be heavily scrutinized by hostlands and the homeland state of Sri Lanka that allows such a hybrid transnational space to exist, where both the diaspora and homeland can exist as one.

\section{The Reconfiguration of the Tamil Identity for Diasporic Tamils}

Although this research study does not focus heavily on identity politics, to understand the diaspora's involvement in homeland affairs, the transnational and shared nature of the Tamil identity should be explored. Spread across over 50 countries, there are approximately 70 to 130 million Tamils in the world today (Burgio, 2016, p. 107). The conceptualization of the Tamil identity is quite complex, varying across nations, because it is differentially understood from the perspective of the diasporic community and the homeland (Thurairajah, 2017). Burgio (2016) argues that the diaspora is continually moving; coining this condition as "living in mobility" ( $p$. 111). From this perspective, Sri Lankan Tamils remain an ethnic minority group both within their diasporic network as well as in the Sinhala-ized state of Sri Lanka; thereby, defining this unique transnational community as a "stateless diaspora" (Burgio, 2016, p. 111); this ultimately shifts and shapes the multi-generationally layered Tamil identity. Though Tamils are deprived of a homeland, the global Tamil community has been able to create a Tamil society within their 
diasporic hubs (Burgio, 2016). That being said, Atputharajah (2016) raises an important point that concepts such as "hostland" and "homeland" create a polarity, in which immigrant communities will never be able co-habitat with dominant society and call a foreign space "home" (p. 3). Additionally, these concepts instantaneously other the immigrant community, whilst gradually depleting the group's sense of belonging. Within the diasporic networks, the Tamil identity is then reconfigured into this transnational de-territorialized space that continuously saves, restores and celebrates Tamil traditional and contemporary culture and a shared global imagery to sustain the Tamil consciousness. These diasporic networks also offer some protection from the oppression and racism of the dominant community. This is established through the construction of an ethnic safe space that embodies in-group symbolism through language and other cultural indicators, and establishes a communalized sense of belonging within the foreign space. Moreover, there is also an apparent divergence between first and second-generation SLTs within the diaspora. Because of the generational factor, a key element about the diaspora is that there are multifaceted levels of ethnic identification with different implications. The fluidity and flexibility of identity then allow some diasporic Tamils to be overtly proud to embrace Tamil identity in its entirety, whilst others may feel more united with their hostland's nationality, as well as those that identify strongly with both national and ancestral identities. The Tamil identity can then take form in the "Tamilization" of the urban space, using symbolism and language as ethnic markers for shops, community events, religious institutions, political manifestos and more. Burgio (2016) provides an abundance of examples that showcase the "Tamilization" in Canada, England, France, and USA (p. 112-113), whilst further conveying that such imagery allows for the Tamil community to recreate and celebrate the Tamil identity in a new deterritorialized space, where the transmission of Tamil memory keeps this ethnic consciousness 
alive. This is more than just a mechanism of settlement and integration, it is a way for the Tamil identity to be distinguished and recognized from that of the foreign environment.

\section{The 1.5 to Second-Generation Tamil Identity}

The 1.5 to second-generational Tamil identity is unique because it functions amid an additional national allegiance and identity with the diaspora's "hostland". To clarify, "1.5 generation" immigrants refer to persons who immigrate within or before their early teens; and may therefore experience a greater degree of acculturation, while "first-generation" refers to persons born outside of Canada, who have immigrated to this foreign land, and have been naturalized within that native culture. Second-generation is consequently the children or grandchildren of the first-generation populace. In a study conducted within Toronto, Atputharajah (2016) found that the second-generation SLT diaspora demonstrate a hybrid identity; leading to the conclusion that this identity is not fixed, as it is constantly changing. Atputharajah (2016) also states that hybridity is the de-territorializing of identity that allows for a multitude of attachments to two or more ethnic origins or nationalities (p. 10). In a way, the nature of this second-generation SLT diaspora goes against ethno-nationalist ideals, as it diminishes the need for borders and allegiance; however, the lack of allegiance to a nation state does not constitute as disloyalty to the national group of the diaspora and/or to their homeland (Atputharajah, 2016). Within Sriskandarajah's (2014) Canadian study, second-generation Tamil participants expressed that they could not separate their Canadian identity from this Tamil identity, as both function to produce feelings of belongingness to both the dominant society and within the diasporic realm of host countries. O’Neill (2015) explains that participants who display a hybrid identity can revise their cultural heritage to facilitate the adaptation process to the transnational location and its material conditions by collectively and individually testing 
cultural norms within this given space. Ultimately, second-generation youth are provided with “accumulated heritage" by their ethnic communities in which manufacture social and cultural reproduction that yield generational change between second-generation youth and their parents. In many cases, second-generation youth have not actually visited Sri Lanka; therefore, their homeland is an essence of imagination. The multicultural framework of this state provides a complex space for the (re)negotiations of the Tamil identity as it is always shifting due to external perceptions and influential factors. Exploring the Tamil identity provides context in understanding the emotional attachment to the "imagined" or "real" homeland that compels the SLT community to engage in various resettlement and sustainable development efforts in Sri Lanka.

\section{METHODOLOGY}

\section{Research Design}

For this study, primary qualitative research was conducted in Canada and in Sri Lanka using an interpretive phenomenological approach to explore the various methods of post-war engagement by the SLT diaspora in their homeland, and the lived experiences of Tamil civilians in post-war Sri Lanka from the interpretive perspective of the Tamil organizations that participated in this study. A crucial principle of Martin Heidegger's interpretive phenomenological approach is that an individual's narrative or "lifeworld" (Lopez \& Willis, 2004, p. 729) dictates their everyday experiences, as humans cannot detach themselves from the world (Lopez \& Willis, 2004; Matua, Van Der Wal \& Dirk Mostert, 2015). Therefore, Heidegger believes in the interpretation and description of the human experience, eliminating the assumed criterion to bracket or mitigate biases and maintain impartiality, as researchers become innately 
entangled within the human experience in question (Lopez \& Willis, 2004; Matua, Van Der Wal \& Dirk Mostert, 2015). That said, my research study's inquiry into the perception and influence of the Tamil diaspora within their homeland and the lived experiences of Tamil civilians in Sri Lanka as described by the key informants, encapsulate the interpretative nature of the phenomenological approach employed within this study. To reiterate, the two-fold research question that led this study is as follows: (1) Is the perception of the global Sri Lankan Tamil diaspora reflective of the present ground realities in their homeland?; and (2) Can the Tamil diaspora influence the Sri Lankan state with regards to social, economic and political outcomes favourable to Tamil civilians in Sri Lanka while assisting the latter with post-war resettlement?

Due to the short three-month period given to conduct this research, I was limited to a sample size of eleven research participants. All my research participants are "key informants" within the SLT transnational space, which will be further discussed in later sections. Although the study was very limited in scope, this empirical approach allowed me to collect information and phenomenalize the post-war experiences and development concerns of those living within and outside the borders of the "real" or "imagined" homeland (Creswell \& Poth, 2018). As recommended by the overall phenomenological approach (Creswell \& Poth, 2018), interviews were conducted to understand current transnational development projects between SLT diasporic communities and their homeland, and to investigate the complex nature and varying opinions regarding the involvement of the SLT diaspora on the ground, in Sri Lanka. Furthermore, I was able to travel to Sri Lanka for a month in June 2018, and conduct interviews with key informants living in the nation-state. In order to conduct such research internationally, I received approval from the Ryerson's Research and Ethics Board (REB), Ryerson International, as well as the Vice-Provost and Dean of Yeates School of Graduate Studies, Dr. Jennifer Mactavish. 
Additionally, all research participants signed consent agreements prior to their interviews that gave them the option to disclose or conceal their personal identity and the identity of their affiliated organization. An example of the consent agreement used in this research study can be found in the Appendix section of this paper. Lastly, a letter from Ryerson International was submitted to the Human Rights Commission of Sri Lanka, indicating that I have obtained approval from Ryerson to conduct my research, while also substantiating my status as a graduate student in Canada.

\section{Sampling Design}

Due to the sensitivity of this topic, I decided to narrow my sample size to very specific organizations and participants that were hand-selected or referred to me using the snowball sampling research technique. Snowball sampling is a non-probability referral technique in qualitative research that permits research participants to identify and recruit potential participants that have aligned interests to the study in question (Biernacki \& Waldorf, 1981). Furthermore, two methods of recruitment were utilized, either phone or e-mail. To participate, the research participant must identify as a "key informant" within the SLT community, whether that be within a diasporic community, in Sri Lanka or between both places. The combination of these three spaces will be de-territorialized and identified as the Tamil transnational space. For this study, a key informant is then defined as Community Leaders in Sri Lanka, Executive Directors, Research Directors, Senior Researchers, Board members, City Councilors, University Professors and other heads of organizations, who play a key role in ongoing development initiatives in Sri Lanka. These key informants also must have first-hand knowledge in diaspora-homeland affairs and updated information on what is taking place within the SLT community in the diaspora and/or in their homeland of Sri Lanka. Furthermore, it is important to acknowledge that the 
Tamil identity is comprised of various nationalities and ethnicities. In fact, Tamil is not synonymous with immigrants from Sri Lanka. Tamil is also spoken by Indians, Malaysians, Mauritians, and many more. Thus, there is a specific inclusion criterion for this study stating that participants must identify as Tamil with ancestral roots to Sri Lanka. Additional criteria for participation are as follows: Firstly, informants must represent an organization, institution, forum, or council within the Tamil transnational space; and secondly, all participants must be above the age of 18 . There were no restrictions made with regards to the participant's gender.

\section{Interviews}

Eleven semi-structured interviews were conducted using the developed interview guide; this guide consists of open-ended questions intended to prompt discussion. Six of the interviews were conducted predominantly in English, three were strictly completed in Tamil, and two were conducted in Tanglish (macaronic language that is a combination of Tamil and English). Each interview was audio-recorded with the ongoing consent of the participant and was later transcribed into English. Caution was exercised in accurately translating the Tamil and Tanglish interviews to English to minimize bias and avoid personal interpretations of data during the transcription process. Ten of the interviews were conducted in person, and one participant was interviewed via Skype. Aside from the single interview conducted through Skype, three interviews were conducted in Canada and seven interviews were conducted in Sri Lanka. The interview process included questions about the following:

i. The participant's role in their respective organization, ongoing projects, or partnered initiatives with other Tamil organizations.

ii. Their opinions on the militarization of the state and whether it has presented any barriers.

iii. What social or public services in Sri Lanka need the most attention.

iv. Thoughts on the global Tamil diasporas development efforts post-2009 as well as some practical ways the global Tamil diaspora can get involved.

v. Whether the conversation about Tamil Eelam, the autonomous Tamil state, should be shifted to address an alternative way of thinking about this group. 
After conducting and transcribing all eleven interviews, the collected data was coded using open, axial and finally, selective coding methods (Creswell \& Poth, 2018). By utilizing these various coding schemes, several themes emerged from the data that will be further discussed in the Findings section of this paper. I must emphasize that, despite this relatively small set of data, great insight was established; especially regarding the current conditions of the homeland and knowledge about the global SLT diaspora's methods of mobilization in the post-war era.

\section{Research Participants and Affiliated Organizations}

This section is to recognize each participant and their affiliated organization, as this study would not have been possible without them. Although not traditionally found in qualitative research studies as is anonymity, the research participants listed below have all formally consented to being identified in this study. The rationale behind this approach was to verify the credibility of this study, which is rooted in the influence and work of these "key informants" and their affiliated organizations within the Tamil transnational space. Amongst the eleven participants, only one, from Sri Lanka, chose to refrain from identifying their name or affiliated organization, but has agreed to be identified as a government official without any gender markers. Please find below the names of each research participant (alphabetized by last name), their affiliated organizations and a short description of each respective organization:

Anushani Alagarajah is the Senior Researcher for Adayaalam Centre for Policy Research (ACPR) located in Sri Lanka. Alagarajah is also an activist who is devoted to the fields of gender rights, development and post-war issues. Commencing operations in 2016, ACPR is a not-for-profit research think-tank that addresses public policy concerns, whilst distinctively focusing on the "Tamil polity" in Sri Lanka (ACPR, 2017). The mission of ACPR is "to be an active contributor of informed and research-based activism within the Tamil polity, to 
report on public policy issues that are of special relevance to the North-East of Sri Lanka, to create internal capacity for autonomy and self-government in the North-East and to contribute critically towards justice, accountability and sustainable peace in Sri Lanka" (ACPR, 2017).

Aiyoob Azmin is a Sri Lankan Tamil Muslim politician. Azmin is a major advocate for the resettlement and rehabilitation of the Muslim populace of the island and a member of the Northern Provincial Council (NPC) in Sri Lanka. Since 2006, Azmin has been a member of the People's Movement for Good Governance. He is also associated with the Illankai Tamil Arasu Kachchi (ITAK), a constituent party of the Tamil National Alliance and a political coalition that represents the Sri Lankan Tamil ethnic minority in the country (Azmin, 2018).

Rasiah Jenakumar is the President of the Jaffna Chamber of Commerce in Sri Lanka. The Jaffna Chamber of Commerce is a non-profit independent organization that focuses on networking and business support, especially for war-affected Tamil civilians living within the Jaffna District of Sri Lanka. According to Jenakumar (2018), there are currently over 1,200 members with the Jaffna Chamber of Commerce. The organization represents the interests of a number of companies - including small businesses - connects business people, acts as a liaison between traders and government bodies as well as other organizations and offers their members a variety of practical and professional services (Jenakumar, 2018).

Tasha Manoranjan is not only a lawyer but also the Founder and Executive Director of People for Equality and Relief in Lanka (PEARL) (www.pearlaction.org; Twitter:

@ PEARLAlert). It is imperative to note that she is one of the very few Tamil female Founders of a SLT diasporic organization to date. Based in Washington, D.C., PEARL is a non-profit organization and advocacy group founded in 2005. It is led by passionate human rights activists 
who are concerned about the situation in Sri Lanka, actively engage with Tamil diasporic communities, and conduct extensive field research that focus on issues affecting the Tamil community in the North-East of Sri Lanka. Furthermore, PEARL has shown its commitment to those in the homeland by persistently advocating with U.S. policy makers, the United Nations, European Union and other governmental and non-governmental organizations (PEARL, n.d.)

Kumaran Nadesan is a Senior Business Consultant for the Ontario Ministry of Government and Consumer Services as well as the Founding Chair of Comdu.it (www.comdu.it; Twitter: @comduit).Comdu.it is an apolitical non-profit organization that is comprised of "diaspora changemakers committed to the sustainable development of the North and East of Sri Lanka" (Comdu.it, 2018). Although this organization is based in Canada, they have extended to Germany and have created many partnerships with institutions and organizations in Sri Lanka. This growing global network has devoted their efforts to shifting diasporic involvement in the homeland from a charity-based nexus to a sustainability framework that values a knowledgebased economy and the productive utilization of diasporic resources to yield long-term change (Comdu.it, 2018). Comdu.it offers placements with various organizations in Sri Lanka for a minimum of one-month; however, such appointments can last for approximately three to six months or longer at the discretion of the local partner(s) (Comdu.it, 2018).

Dr. Thusiyan Nandakumar is not only a medical doctor, but also wears the hat of a political activist, a journalist, and an Editorial Board Member for Tamil Guardian. Additionally, he was the former Editor-in-Chief for Tamil Guardian as well (www.tamilguardian.com; Twitter: @TamilGuardian). Established in 1988 and based in London, England, Tamil Guardian started as a print newspaper, but eventually transformed into a digital news portal in 2011 , covering 
global Tamil and international affairs from a Tamil perspective in the English language (Nandakumar, 2018).

Selvaranee Nicholaspillai is the Director of Planning for the District Secretariat of Jaffna (www.jaffna.dist.gov.lk) in Sri Lanka. The Jaffna District is among the 25 districts of the nation, which is then headed by the District Secretariat; the second-level administrative body of the island (District Secretariat - Jaffna, n.d.). Nicholaspillai's responsibilities within the District Secretariat of Jaffna include: the "establishment of a database related to district development, providing housing facilities for vulnerable families, the implementation of resettlement work for resettled families, coordination of stakeholders, promotion of human resources through skill development training, as well as the optimum utilization of District resources" (District Secretariat - Jaffna, n.d.).

Dr. Muttukrishna Sarvananthan is the Founder and Principal Researcher of the Point Pedro Institute of Development (PPID) (www.pointpedro.org) in Sri Lanka. Established in 2004, PPID is an independent private multidisciplinary research institute that focuses on the regional aspects of economic development in Sri Lanka. Furthermore, the organization also conducts widespread research on the Northern and Eastern provinces, having published numerous works on the topic. The primary objective of this organization is to "empower the people of the Eastern and Northern Provinces, [whom have been heavily affected by the armed struggle], to emerge out of serfdom towards freedom" (PPID, 2018).

Neethan Shan (www.councillorshan.ca; Twitter: @NeethanShan) works for the City of Toronto in Canada as the City Councillor for Ward 42, which encompasses Rouge River, Scarborough. He is well-known within the SLT diasporic community of Canada and currently sits on several boards; these include but are not limited to the Government Management 
Committee, Toronto Arts Council, Toronto Zoo Board of Management, and the Scarborough Community Council. Shan has also been appointed as the City of Toronto's Newcomer Advocate and Youth Equity Champion (Shan, n.d.).

Dharmalingam Thanakumar is the Regional Project Coordinator for the United Nations Development Programme (UNDP) (www.lk.undp.org; Twitter: @UNDPSriLanka) in the Jaffna District of Sri Lanka. The UNDP has been a key development partner in Sri Lanka for over 50 years. Independent from, but working closely with, the District Secretariat of Jaffna, the Jaffna UNDP office is working towards achieving "sustainable development in economic, social and environmental fronts" (UNDP Sri Lanka, 2018). Furthermore, the UNDP is focused on the Sustainable Development Goals, in hopes of "eradicating extreme poverty, and reducing inequalities and exclusion to protect both people and the planet" (UNDP Sri Lanka, 2018).

\section{Disclosure}

As a graduate student who is conducting primary qualitative research, it is imperative to discuss my closeness to this subject matter of homeland-diasporic affairs. Given the ethnic derivation and length of my name, it is no surprise that I am in fact Sri Lankan Tamil. I hold a relatively privileged position in this research due to the duality of my insider and outsider positions. I am an insider due to my Sri Lankan Tamil identity and my fluency in the Tamil language; however, I am also an outsider because of the reality that I am a second-generation Sri Lankan Tamil born in Canada, raised in a middle-class family, and therefore, not immersed in the war-torn environment under analysis. Nonetheless, having many extended family members affected by this protracted war, my empathy is fully attuned with the presenting cognitions and emotions. 


\section{Limitations}

Firstly, the lack of time and available institutional resources/support have been a definite weakness, especially because I conducted research abroad.

Secondly, I must address the lack of female participants in this study. Amongst the ten participants that consented to be identified, only three identified as female; speaking to the underrepresentation of women, especially racialized women, in decision-making positions. From a feminist perspective, this is empirically limiting as it reduces the likelihood of women advancing to top executive leadership positions, further excluding them from influential administrative spaces, peace development circles and research studies such as this one (Abramo, D’Angelo \& Rosati, 2016). This is a systemic issue, dispersed across various disciplines, where white male networks tend to hold more social capital at their disposal, in comparison to any female or minority network. In the case of Tamil transnational spaces, Manoranjan (2018) identified that unlike PEARL, "there aren't any other diaspora organizations, that [she] know[s] of, led by a woman. It's also run by young professionals, whereas all the others, like in the political advocacy space, are led by older men." It is no surprise that there is a lack of literature on the absence of Tamil women in leadership roles within international development spaces; however, that is a whole new avenue of research that is to be exclusively explored. This gap limits the form and allocation of humanitarian aid and post-war development initiatives given to war-affected communities that unfortunately, conform to the assignment of gender roles in a heavily patriarchal society, such as Sri Lanka. In sum, the gender bias excludes the female voice; thus, limiting the scope of my research and the possible outcomes.

Another profound limitation is that my research is solely based on the institutional understanding of diasporic engagement in homeland affairs, as opposed to a combined research 
approach inclusive of diaspora organizations and the experiences of Tamil civilians in Sri Lanka. Although large insights emerged from the research subjects, it is almost unjust to assume that the visions and missions of these organizations are reflective of the overall views and aspirations of the entire Tamil community in Sri Lanka. Moreover, the theme of "civil society capacity building" kept reemerging in the data. Although this concept will be discussed in detail in the Analysis section, it is being identified at this stage to acknowledge that Tamil non-profit development organizations, managed by persons from the West, will predominantly focus on intellectual heritage and epistemological institutionalism. "Civil society capacity building" is a significant component to sustainable development that should not be overlooked, but I cannot definitively state that this is what the Tamil community in Sri Lanka requires or desires. I also cannot conclude that it is working. Both government officials and Jenakumar (2018) referred to the term "hand and mouth solutions" (Anonymous, 2018; Nicholaspillai, 2018); arguing that the most basic and life-saving needs and ultimately, fundamental human rights, such as access to food, water and shelter, must be met prior to creating field-specific capacity-building programs for war-affected minority populations. Alagarajah (2018) further attests to this by stating: "Without food, I don't know, without proper mental health support ... It's just, about living. I know my parents would have done anything to just, like feed us. If that means working for the military. They would have done that." This passage brings forth great insight on the dichotomy of Westernized representations of development needs and civilian-informed development requests. Alagarajah (2018) explains that although it has been nine years since the end of the conflict, basic human needs have not been met by the state or NGOs, and the mere livelihood of the Tamil populace is still suffering. In the case of shelter, displacement and resettlement concerns must also be prioritized by the Sirisena administration to truly commence the positive 
peacebuilding process (Price, 2010). Many key informants also referred to the drastically abridged presence of NGOs in Sri Lanka after the Rajapaksa regime extruded NGOs out of the island during the last phase of the war; a period of urgent need for humanitarian and international assistance (Anonymous, 2018; Nicholaspillai, 2018; Jenakumar, 2018; Alagarajah, 2018;

Nandakumar, 2018; Manoranjan, 2018). According to all key informants, militarization is in part a huge problem that has created various social, economic and political barriers to the Tamil community in Sri Lanka. One of the reasons why I chose not to interview Tamil civilians in Sri Lanka is because I cannot guarantee the safety and security of this vulnerable group. It would have been extremely unethical and exploitative to use a displaced populace in this research study, as a means of retaining information without providing reimbursements, definite security solutions or warranting anonymity. Militarization has been embedded in Sri Lankan society and culture for decades; so much so that it has acquired a new political and economic significance in the post-war era. This concept will be further explored in the Findings \& Analysis section of this paper.

\section{FINDINGS \& ANALYSIS}

\section{The Militarization of Post-War Sri Lanka}

In the context of Sri Lanka, militarization is a structural process that allows for the ideological and institutional infiltration of “civilian militarism” into civil society. Rodriguez's (2018) definition of “civilian militarism”, in conjunction with Oxford Dictionary’s (2018) classification of "militarism" is cooperatively applicable in the case of Sri Lanka, wherein the maintenance of a strong military capability, "increased military presence within society, and the promotion of the militaristic values within society" (Rodriguez, 2018, p. 110-110) are all 
essential influences to preserve, secure and endorse the Sri Lankan state's national interests (Oxford Dictionary, 2018). The heightened military presence, while heavily dominant during the decades of warfare (between 1983 and 2009), became increasingly prominent during the postwar era that began after the fall of the LTTE in May 2009 (Goodhand, 2012). "Civilian militarism" has then been rationalized through the strengthened implementation of the national security state apparatus into the post-war national development agenda to strategize against the possible reemergence of any insurgency (Nadarajah \& Sriskandarajah, 2005; Vimalrajah \& Cheran, 2010; ACPR \& PEARL, 2017; Goodhand, 2012). As Sri Lanka continues to recover from the protracted ethno-nationalist conflict, the militarization of the state is increasingly normalized due to the extensive military involvement in civil affairs. The Sri Lankan armed forces is comprised of the Sri Lankan Army, the Sri Lankan Navy, and the Sri Lankan Air Force, with the current president of Sri Lanka, Maithripala Sirisena as the Commander-in-Chief (ACPR \& PEARL, 2017). Assumingly, the end of the war and especially, the fall of the LTTE would mean that there would be a decrease in military recruitment; however, leaked documents revealed otherwise, as there were plans in place to double the size of the armed forces by 2015 (Widger, 2016). In a comprehensive report regarding militarization produced by Adayaalam Centre for Policy Research (ACPR) and People for Equality and Relief in Lanka (PEARL) (2017) referred to the International Institute for Strategic Studies' 2017 report 'The Military Balance', which found that the Sri Lankan military has 243,000 active members, which is larger in size than the military in France, Israel, Saudi Arabia, and the United Kingdom. Even prior to the end of the conflict, rather than taking a human rights approach to post-war and peace development, militarization was strategically employed and normalized by the Rajapaksa regime to grasp control of the Sri Lankan populace. In addition, the military's extensive involvement in 
civilian affairs surpassed margins prescribed in a constitutional democracy; further securitizing certain identities (such as the Tamil minority population) and conflict-affected areas (areas also heavily concentrated by Tamils). Thus, Tamil identities were presented as a threat to the state to justify militarization as the only method to counter national threats (Satkunanathan, 2016).

By the end of the war, almost 300,000 Tamil civilians were immediately detained in military-guarded camps in the four Northern districts of Vavuniya, Mannar, Jaffna, and Trincomalee. The purpose of this was to interrogate and filter through them to identity LTTE combatants. Those that were regarded as non-LTTE affiliates began to return to their hometowns; however, properties were destroyed, and many lots of farmland became closed state military zones, leaving thousands homeless and displaced (Ganguly, 2016). As a counterinsurgency strategy, the Rajapaksa regime expanded their military network to deter the possible regrouping of the LTTE in post-war Sri Lanka. As a result, the Sri Lankan Army, Navy and Air Force amplified their involvement into various industries such as tourism, leisure, construction and agriculture (Widger, 2016). According to privately owned enterprises and small businesses in Sri Lanka, investigated by Widger (2016), the invasion of the military in such industries has produced an enormous risk to fair competition, as military owned activities have open access to "free labour" and cheap resources, undercutting private ventures by a large margin (p. 33-34). From the construction and the management of schools in Mullativu (located in the Northern Province) (Tamil Guardian. 2018e), to the renovations of churches in the Killnochchi - initially destroyed by bombing raids orchestrated by the Sri Lankan Army (located in the Northern Province) (Tamil Guardian, 2018f) - the military continues to be involved in civil affairs, perpetuating feelings of resentment among the Tamil community. By performing such philanthropist activities, the government and military forces are then ideologically observed as 
"agents of change" (Pieris, 2014, p. 266), whom are satisfying the national development agenda but disregarding the trauma that is being tolerated by the war-affected Tamil community within the North-East - who have not been consulted. The Sri Lankan Army run resorts, beaches, tourist excursions, hotels, tea boutiques, snack bars, food stalls, barbershops, travel agencies, farmhouses, and many more enterprises on acquired land from internally displaced Tamil civilians (ACPR \& PEARL, 2017; Widger, 2016). In 2010, the military's extensive involvement in civilian space expanded to the extent that the Ministry of Defence was renamed to the "Ministry of Defence and Urban Development", ultimately permitting the alleged re-fueling of the military using tourist expenditure (Roy, 2015; Pieris, 2014). Not only is this reducing employment for those in the Tamil community, but public institutions are being operated and activities are being influenced by militarized bodies that uphold Sinhala-Buddhist hegemonic values, who were also directly involved in the protracted warfare. Additionally, Editorial Board Member of Tamil Guardian, Thusiyan Nandakumar (2018), discussed how the government is currently incentivizing military enrollment, as a means of encouraging the military to stay in their posts; by providing soldiers with family benefits and constructing gyms, tennis courts and other facilities within the camp they are further fortifying and consolidating these military bases. In a qualitative ecological study conducted by Somasundaram \& Sivayokan (2013), on rebuilding community resilience in post-war Sri Lanka, they found that militarization had increasingly distorted democratic institutions and removed the reconciliation processes, while leaving space for recurring conflict. The heavy military presence in the North and the administrative control of Colombo, predominately in the hands of Sinhalese state actors, hindered the revival of community agency, making militarization the first step in accomplishing Sinhala-Buddhist hegemony in post-war Sri Lanka (Somasundaram \& Sivayokan, 2013). That 
said, the Sinhala-Buddhist hegemonic nature of the country's nationalism ultimately inaugurated the ethnic tensions that continue to exist within post-war Sri Lanka today. The island of Sri Lanka, formerly known as Ceylon, was granted independence from Britain in 1948. Since the country reached independence, the Tamil minority populace felt increasingly segregated from civil society and alienated from the political processes of the state (Seoighe, 2016b). Through the Sinhala Only policy and the widespread anti-Tamil riots that swept the island, in addition to other exclusionary and violent practices of nationalism, Tamils continued to feel othered within the borders of their own state (Nadarajah \& Sriskandarajah, 2005). It was due to the institutionalized Sinhalization of the island that led to the ensuing formation of the LTTE, as a response to the oppression of the Tamil community in Sri Lanka committed by state actors, laws and governance (Seoighe, 2016b).

\section{Militarized nationalism}

Acknowledging the history behind the formation of the LTTE, it is imperative to note that the Tamil response to Sinhala national oppression can arguably be viewed as a form of militarized nationalism as well. According to Nadarajah \& Sriskandarajah (2005), the LTTE described itself as a "national liberation movement deeply embedded in [the] people, articulating the wishes and aspirations of the Tamil nation" (p. 88). Militarized nationalism normalizes military capability within the state as exemplified through the institutionalization of the organization through its civil administrative structure (Nadarajah \& Sriskandarajah, 2005). Just as the Tamil community viewed the ethnic hostility as systemic tyranny and violence committed by state security and armed forces, the Sinhalese perspective saw militant violence "as conducted on behalf of and endorsed by the independence-seeking Tamils" (Nadarajah \& Sriskandarajah, 2005, p. 93). As discussed in an earlier chapter, the LTTE controlled over $70 \%$ of the Northern 
and Eastern provinces of Sri Lanka that was highly concentrated by the Tamil minority group (Nadarajah \& Sriskandarajah, 2005, p. 89). Such militarized control within civil society as well as their fight for an autonomous Tamil state arguably illustrates a militaristic approach to Tamil nationalism.

The war had depleted much of the Tamil community and now the heightened military control, embedded in the political and social fabric of state, has produced militarized nationalism in Sri Lanka. The military presence is, larger, stronger and better equipped with artillery than police forces, which further normalizes its existence (Hyndman \& Amarasingam, 2014). The Sri Lankan government utilizes militarized nationalism in the post-war era to produce the national and international threat of the "Tamil Tigers", with the intention of stabilizing militarization in civilian spaces (Hyndman \& Amarasingam, 2014). The rationalization of civilian militarism and militarized nationalism within Sri Lanka allows for state security forces to impose on civilian activities and industries, while overlooking state laws with ease. Although Sri Lankan domestic laws explicitly indicate that "land must be used for public purposes" (ACPR \& PEARL, 2017, p. 14), the nationalistic dynamic of this type of militarization is further entrenched in the pardonable allocation of land to the military, that is then standardized as a public purpose because the military is an extension of the state (ACPR \& PEARL, 2017). The normalcy of militarization integrated into civilian space is then corroborated by Sinhala-Buddhist hegemony through the overwhelming presence, continued construction, and careful maintenance of Buddhist temples in the North-East; meanwhile, homes of the war-affected Tamil civilians have been occupied by military camps, destroyed, or remain in poor conditions (ACPR \& PEARL, 2017). 


\section{Militarized masculinity}

It is imperative to acknowledge the presence of militarized masculinity within this combatant culture space. Notably, Sinhalese military men are often exhibited as "heroes", with militarism being marketed as a path to a "good life" (de Mel, 2009, p. 36), and any person that opposes this notion of national identity will be subjected to persecution. That said, the deceased combatants of the LTTE are also recognized by many members of the Tamil community in Sri Lanka as well as the global diaspora as "heroes." However, it is the selective nature of the freedoms granted within the process of the memorialization of both clashing troops, by their respective followers, within public spaces in Sri Lanka, that produce a variance in the experience of honouring heroes. In the Interpretations of Memory section of the Findings \& Analysis chapter of this paper, the intentional suppression of the Tamil narrative and Tamil memorialization due to Sinhala nationalistic ideals is discussed in detail. Because the Sinhala nationalist ideology is also composed of the militarization of the state, militarized masculinity has been resultantly redrawn and reinforced through the social and political order of the state (De Mel, 2009). Tapscott (2018) suggests that militarized masculinity also shapes a binary between military men and a feminized space that needs protection - creating a form of possessive territorialization, as exemplified in the conversion of Tamil civilians' farmland into military zones. The widespread circulation of Sinhala-Buddhist hegemony has fashioned a prominent parallel between nationalist ideology, popular culture, and practices in Sri Lanka (Rampton, 2011, p. 261). Because Sri Lanka has been deeply rooted in conflict for centuries, the promotion of war and the idealized concept of the male soldier protecting the land and his family is an essential and normalized tool of being. 


\section{Militarization as a Barrier to Diasporic Engagement \& Positive Peacebuilding}

Almost all research participants (nine out of eleven participants) identified that militarization is a barrier that manufactures trepidation towards diasporic engagement in homeland affairs, and delays the overall peacebuilding process. The remaining two participants, who are both civil servants, chose not to comment due to their official positions, which further demonstrates their apprehension, as well as the Tamil community's anxiety of vocalizing sentiments that counter state activities, especially while residing in Sri Lanka. "It's dangerous to be a journalist in Sri Lanka but it's life-threatening to be a Tamil journalist in Sri Lanka", said Nandakumar (2018). Some organizations such as Tamil Guardian, Nandakumar's (2018) affiliate organization, have been directly impacted by militarization due to the journalistic nature of the organization and the state's fears of exposing internal affairs. That said, the Tamil diaspora's aptitude to influence the Sri Lankan state on social, economic and political outcomes favourable to Tamils in Sri Lanka is relatively difficult and complex, owing to the structural determinant of militarized nationalism. Militarization reproduces Sinhala-Buddhist triumphalism by diminishing the Tamil community's capacity for collective civic engagement, distancing Tamil civilians from democratic discourses (Pieris, 2014, p. 269), and deterring their involvement from post-war reconstruction processes of the North-East. Although militarization is seen as a barrier to the positive peacebuilding process, the standardization of the military's participation in civilian spaces and their contemporary presence as "agents of change" (Pieris, 2014, p. 266) does not provide the state with an obligation to halt military recruitment or to demobilize their armed forces. 


\section{Personal Observations}

During the brief period I spent in Sri Lanka, the dominance of militarization within the North-East was quite apparent to the foreigner's gaze. As I was reading Seoighe's (2016a) article, titled Discourses of victimization in Sri Lanka's civil war: Collective memory, legitimacy and agency, while travelling down the A9, a 321-kilometer-long highway, from the capital city of Colombo to Jaffna - one of the assumed spaces of Tamil Eelam - I noticed the abundance of army camps that stretched for yards. While spending most of my time in Jaffna, the presence of the military occupying civilian spaces was very visible, whether that be at church festivities such as their involvement in the St. Anthony's festival, where jets flew above and released petals across the church facility, or amongst civilian administrative arenas. As acknowledged by many of my research participants and various scholars (Seoighe, 2016b; Widger, 2016; Rampton, 2011; Gaul, 2017; Satkunanathan, 2016; Goodhand, 2010; Hyndman \& Amarasingam, 2014), the army has in fact infiltrated employment, social and educational spaces specifically in the NorthEast of Sri Lanka. However, much of this militarization is not found within the South of Sri Lanka, in addition to many other regions where most of the population identifies as Sinhalese. Travelling through Vavuniya using the A9, the Sinhalization of Tamil land is evident through the construction of Buddhist shrines. Tamil Guardian (2017) further discussed how "[Hindu] worshippers say they cannot go about their activities freely" due to capacity issues, the overwhelming presence of the military, and the Buddhist fence that has been infringing upon the Hindu temple for some time. Moreover, the presence of the military is very rampant in the tourist industry, which was evident during my visit to Kankesanthurai or KKS beach which was a former naval hub; nevertheless, a Sri Lankan Navy base still exists within that area (Tamil Guardian, 2018b). Aside from the physical presence of the military, the most astounding moment 
was acknowledging the ideological normalization of militarism as exemplified through the utterance of my 9-year old cousin. "Boom boom boom, a shell has fallen on your house, where will you run?" This is an innocent hand-game joyfully played by him and his friends at school, located in the LTTE's northern stronghold, the Vanni region of Sri Lanka which was hit the worst during the time of combat. Born during the last phase of the war, my cousin demonstrates the transmission a psychological narrative that is rooted in the desensitization to violence. This is the compounded result of decades of past adversity and the presence of the present day highly militarized post-war environment. Nandakumar (2018) states that, "genocide doesn't necessarily involve the mass killing of hundreds of thousands of people... when they talk about genocide in the [Sri] Lankan definition, it talks about actually tearing away at the social fabric of the nation and of the people and this is kind of what's happening." Furthermore, this exemplifies the longterm effects of cultural genocide and the colonial ideological dominance of an internally militarized and an externally Sinhala-Buddhist nationalistic social order that exists in Sri Lanka's post-war environment (Seoighe, 2016b; Rampton, 2011).

\section{Solutions to Militarization}

Finding and implementing strategic solutions to this level of militarization in a post-war state is a complex task; there are several schemes proposed by various stakeholders that the Sirisena administration and the Tamil diasporic community can utilize to address this concern. Sarvananthan (2018) discussed the principle of proportionality in military science that has been deemed crucial under international humanitarian law to enforce regulation in combat operations. Recognizing both the Protocol Additional to the Geneva Conventions of 12 August 1949, and relating to the Protection of Victims of International Armed Conflicts (Protocol I), 8 June 1977 as well as Customary International Human Rights Law-Rule 14: Proportionality to 
Attack, the International Committee of the Red Cross (2018) summarizes the "principle of proportionality" as a standard that "seeks to limit damage caused by military operations by requiring that the effects of the means and methods of warfare used must not be disproportionate to the military advantage sought." Therefore, considering that the warfare has formally come to an end, the disproportionate ratio of soldiers to civilians within Tamil populated areas such as Mullaitivu District, where there are 60,000 military bodies and one soldier per every two civilians is simply unjust (ACPR \& PEARL, 2017, p. 4). Given the aforementioned data provided by two key informants in this study, ACPR \& PEARL (2017), the Mullaitivu District has been identified as "one of the most heavily militarized regions in the world" (p. 4). Additionally, the report co-published by ACPR and PEARL (2017), titled "Normalising the Abnormal: The Militarisation of Mullaitivu" has also recommended proportionality relocating soldiers throughout the island rather than concentrating them in the North-East and transferring military owned land and businesses to Tamil civilians (p. 31-32). This report has provided a multitude of recommendations to the government of Sri Lanka, the Tamil polity and the international community and to explore these recommendations, do visit the above report to find well-researched and detailed suggestions (ACPR \& PEARL, 2017, p. 31-32).

Although not his sole view, Sarvananthan (2018) also proposed an alternative perspective that suggested there may perhaps be an increase in petty crimes if soldiers were discharged; retrospectively however, most research participants (eight out of eleven participants) discussed the benefits of state programming that focused on the disarmament, demobilization and reintegration of Sri Lankan armed forces into civil society as civilians rather than combatants. Manoranjan (2018) points out that:

"Intentionally, they [the Sri Lankan military] are positioned in the Northeast, and in the Tamil homeland, in order to instill that fear and instill that culture of oppression against 
the Tamil people. I think there are lots of ways to demilitarize because there has not been active conflicts since 2009, so there's no reason, for now almost 10 years later, for the military to be staying at the same levels, or higher, as when it was active conflict ... There are solutions. It's just a question of political will, and the government clearly doesn't have the political will to demilitarize. I think that's the larger problem. It's not that they don't know how to demilitarize. It's that they don't want to demilitarize."

As for the Tamil diasporic community, it is imperative that they take responsibility for immersing into their privilege of return mobility to the homeland by exercising ethical tourism alternatives. To be an ethical tourist in Sri Lanka, one must undertake research in the current post-war state of Sri Lanka to simply get informed. Through research, an ethical tourist can also find various family-run restaurants, hotels and small businesses that are not military-operated. To learn more about how to ethically tour Sri Lanka, a very helpful resource is www.srilankacampaign.org. At this point, it is crucial to note that the recommendations proposed above are only a glimpse into the practical methods that can alter and influence the political, social, and economic conditions of Sri Lanka. That said, militarization continues to be an institutionalized and structural issue that is embedded within the national framework of the state, fostering the normalization of ideological militarism into civilian spaces.

\section{RECOMMENDATIONS ON MOBILIZING THE DIASPORA FOR POST-WAR SLT}

\section{$\underline{\text { UPLIFT }}$}

\section{Civil Society Capacity-Building}

As discussed in the Limitations section of this paper, "civil society capacity building" is a reoccurring theme, cited as a method of mobilization for the Tamil diasporic community by all participants in this study. This section will explore the various ways the key informants of this study are engaging with capacity-building. According to Sterland (2006) the concept of capacitybuilding - deriving from peace and conflict studies - is a theory that engages in a larger 
development discourse that is an essential tool for restoring social cohesion within the postconflict state. However, it fashions post-war societies "according to a Western-style liberal democracy" (p. 1), which is why it is problematized for its presumptive and often, institutionalized position in post-war development discourse. First and foremost, in a post-war society, it is imperative for capacity-building efforts to be geared towards "confidence building" (Sterland, 2006, p. 50). Through this, civil society capacity-building can successfully rebuild communal ties and social trust through the facilitation of knowledge circulation and establishing a "collective social vision" (Sterland, 2006, p. 50). After 2009, the diasporic Tamil community felt demoralized and disempowered due to the displacement of thousands of Tamil civilians and the destruction of the Tamil livelihood- a continued rhetoric echoed all through to present-day Sri Lanka. Capacity-building instills confidence in the war-affected populace to look beyond short-term, "band-aid" solutions that focus solely on monetary assistance and into sustainable, advanced and technologically-savvy methods of post-war progression to be able to compete economically on a global-scale and develop new industries. The research findings of this study suggest a three-fold approach to civil society capacity-building through mentorship programs, international partnerships and the acquisition of social capital.

\section{Establishing Mentorship Programs}

Anushani Alagarajah (2018), the Senior Researcher for ACPR discussed the importance of exchange programs and the need for a network of professionals that guide employment training workshops that provide industry-specific guidance, resources and tools to better the professional portfolios of and encourage young Tamil professionals in Sri Lanka to excel in the workforce. Although the infiltration of the military in employment spaces poses a threat to Tamil civilians' ability to find work, the transference of knowledge and diasporic investments in new 
industries will provide open access to new possibilities for youth in Sri Lanka. Rather than visiting the homeland, much of the criticism is then directed towards using such funds to fuel industries that will then generate employment. As mentioned by Alagarajah (2018), an example of this type of mentorship is ACPR's media capacity building program, collaboratively designed with the Jaffna Press Club and Tamil Guardian for journalists in the North. The training focused on investigative journalism; how to conduct interviews, accountability, video-editing, photography, story-telling and much more (Alagarajah, 2018).

\section{The Maintenance of International Partnerships}

Next, international partnerships such as sister-city partnerships provide immersive opportunities for the sharing of resources and the expansion of the Tamil consciousness into international platforms, bringing more attention to the conditions and sustainable development needs of post-war Sri Lanka. Sister-cities of Toronto are cities with which Toronto is politically and terrestrially linked to, with the aim of cultivating human contact and cultural exchange. Mayor John Tory and Councillor Neethan Shan have a sister-city agreement between the City of Toronto and Jaffna city in Sri Lanka (City of Toronto, 2017). Through this partnership, academic resources such as books are being transferred to the new Jaffna Public Library, in hopes of rebuilding the Tamil cultural legacy in the North of Sri Lanka. "It's not about money directly, it's about building capacity, building infrastructure, building partnership, and building solidarity," states Councillor Neethan Shan. Shan (2018) continues to state that this is not simply an imposturous Westernized mode of development work but rather an exchange that will also benefit Toronto by:

"Learning from the resilience of the community there [in Sri Lanka], learning from the post-war management strategies that community has used, and the cultural side of things. There's been a lot of literature and artistic productions that have come out of Jaffna that 
could influence and shape Toronto...but trying to figure out the best way to maximize that is going to be a continuing challenge."

Comdu.it is also an organization that fosters international partnerships throughout various initiatives and regions in Sri Lanka. Some partners in Sri Lanka include: Centre for Women and Development, Ceylon Spinning \& Textile Mills Ltd, Chinmaya Organisation for Rural Development, INFORM Human Rights Documentation Centre, Institute of Regional Development and Governance, Organisation for the Rehabilitation, and more (Comdu.it, 2018). Fostering healthy relationships between Tamil diasporic organizations and institutions in their homeland through exhaustive consultation processes is essential for the diaspora to accurately acknowledge the present ground realities in their homeland, and influence the Sri Lankan state on social, economic and political outcomes. Although criticized for being "voluntourist" in nature by both Tamil communities (Nadesan, 2018), Comdu.it is involved in extensive consultation with its stakeholders to find the most effective methods of leveraging technical expertise from the diaspora, whilst building capacity amongst public institutions in the Northern Province of Sri Lanka (Nadesan, 2018). Some research participants argue that rather than giving opportunities to those in their homeland, the diaspora is taking jobs by having such volunteerbased programs. While other participants contend that such opportunities allow for the Tamil diaspora to reconnect or build connections for the first time with their ancestral roots, compelling them to have more interests in their homeland affairs.

Currently in its third phase, the Northern Livelihood Development Project is an initiative operated by the UNDP to strategize and promote local economic development in the districts of Jaffna, Killinochchi and Mullaitivu (Thanakumar, 2018; UNDP Sri Lanka, 2018). This is achieved by "increasing the opportunities and capacities of the local communities to engage in sustainable market-based livelihoods" (UNDP Sri Lanka, 2018). This project works with both 
the public and private sectors to develop "existing economic capital through value-addition, product diversification, and skills development" (UNDP Sri Lanka, 2018). Considering that it has been nine years since the end of the war, almost all key informants suggest that it is time to move forward from trauma-based assistance to larger scale ventures that target economic development; however, the reality of re-traumatization caused by the heavy visible militarization of the North-East is an often-excluded factor. The consensus remains the same - it is difficult to build-capacity for the Tamil community in Sri Lanka when there is a lack of equal opportunity for employment due to the infiltration of military personnel in these industries, a Sinhalized educational system, and a lack of political stability (as stated by 9 key informants). That said, for the Tamil diaspora to influence their homeland they must generate opportunities and invest in industries for the Tamil communities to excel in.

\section{Acquisition of Social Capital}

The global Tamil diaspora has been acknowledged for their progressive social, economic, cultural and political influence, and the networks that offer sustainable economic growth and development through their powerful and dynamic source of "social capital" in post-war Sri Lanka. The World Bank (2011) simply defines social capital as "the norms and networks that enable collective action [that is] critical for poverty alleviation and sustainable human and economic development." Bandaralage (2009) goes even further to discuss the varying components of social capital such as "trust" and "institutions" that are inter-related and mutually reliant to become social assets in development discourse. Cheran (2007) finds that the social capital fostered through Tamil transnational networks, offered more than just diasporic financial flow. Instead, transnational Tamil social capital provides resources, expertise, infrastructure development, equipment, and other elements involved in the relief and reconstruction processes 
necessary for the contemporary post-war environment. Unfortunately, ethnic cleansing and mass internal displacement left the Tamil community in Sri Lanka with no foundation for the essential structural elements required to attain social capital and develop these "collective social visions" (Sterland, 2006, p. 50) that reach beyond local and national borders. At this point, the immediate needs included life-saving aid and targeted support by NGOs and various informal and depoliticized channels of humanitarian assistance to support the reconstruction of the Sri Lankan state. In the case of Sri Lanka, for there to be communal solidarity between Tamil and Sinhalese citizens in Sri Lanka, there needs to be a depoliticized and externally oriented NGO-based civil society. Although theoretically sound in nature, it is very difficult to remove the political component from this conversation as it is an extremely politicized conflict and much of the aid and diasporic assistance has been attempted to be controlled by state actors. The overall purpose for civil society capacity-building is then to create sustainable opportunities and remove the dependency of the Tamil community in Sri Lanka from the monetary and charitable support of the diaspora by creating professional networks and assisting in the acquisition of social capital. Although social capital is a perceived outcome of capacity-building and is intended to cultivate economic development, restricted access to power and opportunity due to institutionalized barriers - as exemplified in the case of the Tamil community in post-war Sri Lanka - ultimately confines social capitalization. That said, as reiterated by Vimalarajah \& Cheran (2010), the Tamil diaspora remains a credible actor that can "transcend ethnic boundaries" (p. 8) and create these "power centres" (p. 8) for the Tamil community in Sri Lanka through capacity-building efforts to improve institutions, build democratic processes that support inclusive development efforts, demand accountability and strengthen the Tamil consciousness, networks, and industries for generations to come. 


\section{The Digital Tamil Diaspora}

In this new digital era of globalization, the Tamil diaspora has reconfigured their transnational communality for identity maintenance and political mobilization through a digitized diasporic space. Although the online platform is not a new phenomenon for Tamil mobilization globally, social media platforms and mobile apps have invited wider audiences in online-offline diasporic engagement activities (Kumar, 2018, p. 4). Thus, the Tamil diaspora can be identified as a highly complex node-based "digital diaspora". While a conventional definition of a physical diaspora is "place-based" (Brinkerhoff, 2009, p. 12), according to Brinkerhoff (2009), "individuals within and across such communities can create additional, online communities, or may simply use the Internet to pursue purposive objectives related to their homeland identity" (p. 12). Kumar (2018) found that the Tamil diaspora, which is deterritorialized, exceeding existentiality, has not only been utilized for political mobilization, but has also allowed persons within the community to repossess and reshape narratives and comprehend past traumas involving historical grievances. Nandakumar (2018) found that this digitized space:

"is relatively easy to access but it's also free of government censorship to an extent. This new space has really allowed us to talk about the Tamil struggle in these different platforms and project it to a wider audience...not only is it cheap and not only is it easily accessible, but it also provides really good means of communication so we all can get in contact with sources and journalists on the ground, talk about the different things that are going on and check information really quickly and rapidly all across the world."

Kok \& Rogers (2017) state that transnationalism, through the digital lens, is capable of augmentation; it is redesigned via the web and advanced media technology to be able to negotiate identities, publicly express opinions, and provide solidarity, as well as material assets to its constituents when engaging in homeland affairs (p. 25). In the post-war era, much of the influence of the global Tamil diaspora emerges through access to Internet technology and 
research and policy-based think-tanks, which can and has been employed to leverage social, economic and political outcomes from the Sri Lankan state favourable to Tamils in Sri Lanka. While having the option to maintain anonymity, the Tamil diaspora can publicly voice their individualistic opinions, confront and challenge the Sri Lankan state and demonstrate global solidarity merely through various social media platforms such as Twitter, Facebook and Instagram. In recent events, an example of this use of digitized diasporic space for political mobilization was the recently organized rally by a collective of Tamil activists, in solidarity with the Tamil Families of the Disappeared in Sri Lanka, who have been incessantly protesting for over 500 days across the North-East of Sri Lanka. Advertised predominantly using social media outlets, hundreds attended these global demonstrations alongside their respective communities, to instill pressure on the international community as well as the Sirisena administration to address the demands of these Tamil families (Tamil Guardian, 2018d). Within the post-war context, the Tamil "cyber community" or "digital diaspora" have been able to bond and bridge social capital and this process entrusts solidarity, while exhibiting the successful production of action through the digitized transnational space. Resultantly, the Tamil consciousness has been given the opportunity to spread through different masses and spaces outside of the known Tamil transnational community. Grasping a wider audience through new media technology challenges ignorance and creates a united front for Tamils but also other diasporic communities that are seeking justice within their homeland. Given the security risks for Tamils in the homeland, the de-territorialized and digitized Tamil diaspora has fashioned a safe space to expose, challenge and shame the activities of the Sri Lankan state. By actively reporting, researching and publishing findings, the Tamil diaspora has been able to empower the Tamil struggle and raise their concerns by documenting the atrocities and the militarization of the state, which then can be 
presented as a call for action to the international community and other international governmental bodies. Thus, ground realities are much more difficult to conceal due to the digitized nature of the diaspora and the Tamil perspectives of issues are not omitted in development discourse pertaining to their homeland or other issues, but instead, are being credited and justly recognized. A prominent concern voiced by various key informants on the ground addresses the manner in which the young people's desire in Sri Lanka for new and advanced mobile technology is limiting their desire to excel educationally. Conversely, access to technological resources allows for intellectual growth and internationalized exposure to views outside of the politicized internal affairs of Sri Lanka. This access to Internet technology also bridges the gap between the diaspora and the homeland through the transference of knowledge and experiences of the Tamil identity that is being reconfigured due to its hybrid nature within the Tamil transnational community. Through the digitized space, various diasporic organizations such as Tamil Guardian, ACPR, and PEARL have been able to work together, and Tamil activists have been able to merge ideas and research findings across borders; allowing for the growth of a new transnational space that transcends physical and territorial constraints. Furthermore, due to diasporic mobility, many Tamil diasporic members are returning or visiting the homeland for the first time, which is the case for much of the second-generation Tamil population. Given this opportune occasion, diasporic members can observe, consolidate and corroborate current research on the Sri Lankan state from their own point of vantage. In this digital era, it is imperative to acknowledge that many people from the West retain world news faster through social media platforms than traditional news outlets. That said, the power of social media allows for gathered information - through pictures and texts - to be disseminated and utilized as a tool to "report" and address the respective concern with other diasporic members as 
well as non-members. Arguably, by increasing access to this digitized space between the Tamil diaspora and their homeland, it is probable that awareness can be created, and allies will step forward, cultivating more solidarity and support for the Tamil struggle.

\section{The Interpretations of Memory}

Canagarajah's (2013) study found that the Tamil diaspora employs a multilingual and hybrid construction of the heritage language that is influenced by the host-country's native language, which is predominantly English. However, Tamil elders found their language to directly connect with their ethnic identity; therefore, the loss of heritage language equates to the demise of their entire Tamil identity and consciousness (Canagarajah, 2013, p. 134). The transnational Tamil space has been modified to treat their heritage language as a resource but not a compulsory condition to engage in homeland affairs. The concept of memory is then used as a tool to sustain the Tamil consciousness, amid the normalization of oppression and the systemic imposition of Sinhala-Buddhist hegemonic structures within the Sri Lankan state. All the activities ensued by the key informants in this study contributed to the maintenance and sustenance of the Tamil consciousness. Employing Frayn \& Phillips' (2018) definition of "memory" is the:

"act of representing events, objects and people as we understand them; the particular choices of language, metaphor and other rhetorical devices, and the situation of these within societal structures and frameworks to create a coherent narrative... Memories are not static representations of past events but 'advancing stories' through which individuals and communities forge their sense of identity" (p. 182)

That said, the concept of memory differs within the diasporic space and within their homeland.

Unless an activist is immersed in development work within Sri Lanka, the diasporic interpretation of memory is predominantly defined by the celebratory aspects of discovering and not forgetting the cultural forms of the hereditary and hybrid Tamil identity. An identity that is often competing within the respective diasporic terrain, where an alternative identity exists. 
Memory within their homeland is contending against the oppressive structures of militarization and Sinhala-Buddhist supremacy, focusing primarily on incessantly reviving the Tamil consciousness to remember and honour historical grievances and past traumas. Although homeland and diasporic memory is linked through experience, historical grievances, and past traumas, the current pressing realities and forces by which the identity is competing against is different, altering the central purpose of that memory function. This is not to say that the Tamil diaspora does not honour their historically pivotal moments within the Tamil struggle. In the Canadian context for example, the diaspora's expressions of memory are centered around a multicultural framework that produce a complex space for the renegotiations of the Tamil identity, which continually shifts due to external perceptions and influential factors of the host society. In order to maintain a cultural presence within a predominantly White space, ensuring that the Tamil identity and culture is not forgotten, and a sense of community is maintained, the "festivized" nature of the ethnic community is celebrated. A prime example of this in the Canadian context is the establishment of the Tamil Heritage Month Initiative (Shan, 2018), which takes place in the month of January to recognize the contributions of Tamil Canadians in Canadian society.

Within the Sri Lankan state, the memorialization of Sri Lankan Army "war heroes" is prevalent and occupies space in the form of statues and monuments in highly-Tamil-populated areas of Sri Lanka. ACPR \& PEARL's (2017) found there to be exhaustive state suppression of Tamil memorialization and remembrance activities in the North-East. Additionally, those that attempted to honour their dead were subjected to routine acts of harassment and heightened surveillance by Sri Lanka's Civil Security Department (CSD) (ACPR \& PEARL, 2017, p. 27). As a result, many members of the Tamil community in Sri Lanka have decided against 
participating in such remembrance activities due to the highly monitored nature of these events, the security threat that it poses and the potential hostile response that such involvement may trigger. This securitization and obstruction against Tamil memorialization is heavily found within the Mullaitivu District, located in the Northern Province of Sri Lanka, where the final phase of the war took place. Thousands of Tamil civilians were massacred in Mullivaikkal, a narrow beach strip within the Mullaitivu District where the Sri Lankan Army proclaimed their defeat against the LTTE (ACPR \& PEARL, 2017). Although it may be identified as a point of victory for the Sri Lankan armed forces, it also symbolizes the "last hope" and a place of significance to the Tamil existential existence, consciousness, and memory. Within this district alone there are three war museums and a multitude of monuments honouring the military for their victory; however, local Tamil communities have not been permitted to construct monuments in lieu of the thousands of Tamil civilians that perished during the Sri Lankan military's triumphant win in 2009 (ACPR \& PEARL, 2017). Furthermore, every measure of symbolism that could faintly bring any awareness of the LTTE's ideological stance was demolished; however, what this ultimately meant was that every monument, sign or symbol that had any affiliations with the Tamil community was also erased and replaced (ACPR \& PEARL, 2017). Tamil civilians and diasporic members feel that in the name of security, the new Maithripala Sirisena government is instrumentally destroying any physical manifestations of the Tamil identity, thus, intentionally halting the social progression and mere existence of Tamils in Sri Lanka (Seoighe, 2016a).

In the context of post-war Sri Lanka, the SLT history and identity has been a great source of generationally transmitted trauma. Moreover, the memory of trauma is a representation of the “survivor's pursuit of acknowledgement of their suffering" (ACPR \& PEARL, 2017, p. 27). 
When this right to passage is obstructed, positive-peacebuilding processes are disturbed due to the invasive nature of oppressive state structures that do not allow space for true accountability, reconciliation and justice, suggesting that the survivors' truth is best kept suppressed and hidden. ACPR \& PEARL's (2017) report concluded that regardless of these barriers, Tamil civilians continue to "persevere out of the belief that it is 'their duty' to commemorate those who were lost” (p. 27).That said, for the diaspora to maintain an influence in their homeland's social, political and economic conditions, memory must not exclusively focus on festivities, but instead, it must continuously commemorate and advocate for the Tamil right to memorialization of the historical grievances across the island; especially in the North-East, where the blood of thousands of Tamil cadres and civilians is entangled in the soil of their Tamil land.

\section{The Divergence in Structure and State Responsibility}

The research findings of this study suggest that there continues to be a disparity between the homeland and diaspora's desire for a structured or all-encompassing approach to engagement that entails a single or a multifaceted channel(s) of diasporic involvement. Thus, I must acknowledge the fact that there is a lack of diasporic research participants involved in this study. Guribye \& Tharmalingam (2017) and de Silva (2010) found that the fall of the LTTE left Sri Lanka in a state of uncertainty and the global SLT diasporic community now finds itself in the midst of a leadership crisis, resulting in the dramatic drop in diasporic development aid that postbellum Sri Lanka is reliant on. Because of diasporic development efforts' failure to address the immediate needs of war-tired Tamils, with an increased concentration on long-term political interests to establish a Tamil Eelam, according to Thurairajah (2017), Tamil civilians in Sri Lanka became more resistant to diasporic political engagement. Conversely, according to the key informants of this study, Tamil civilians have been receptive of diasporic engagement in recent 
years; however, these institutional actors do not share parallel views on how this engagement should flow within the Sri Lankan state. Jenakumar (2018), Nicholaspillai (2018), Thanakumar (2018), Sarvananthan (2018), Anonymous (2018), Shan (2018) and Azmin (2018) believe that there is a lack of transparency with diasporic flows of development. Sarvananthan (2018) discussed how diasporic fiscal resources have arguably been put towards "wasteful expenditure" because of the lack of transparency and consultation that takes place during the post-war development process. Sarvananthan (2018) makes his case by stating that diasporic members tunnel funds through independent sources such as school and village associations, which have been utilized to restore and then continuously renovate religious institutions on multiple occasions, while the dwellings and houses of Tamil civilians surrounding that area remain in extremely poor conditions. Moreover, Shan (2018) observed that the first layer of diasporic involvement is assistance through immediate family; however, this is very reflective of "who got out of the country and who's doing well, which part of the homeland has more people out, or at least what part of the homeland has more people in good positions or good businesses, doing well" (Shan, 2018). There is also a level of favouritism amid the dispersion of aid that exists when disasporic assistance is not monitored, creating social inequalities within communities. This favouritism was expressed when Jenakumar (2018) was imparting a post-war narrative that involved the Jaffna Chamber of Commerce's involvement in providing essential aid to the internally displaced Tamil civilians living in camps immediately after the end of the war. Singling out a familiar face from the food line, Jenakumar (2018) selected this rich man who he knew and who had lost all his material possessions, from the crowd and provided him with "all the money [Jenakumar] had in [his] pockets." Although it is difficult to say how to institute a structural solution for diasporic engagement to monitor and regulate allocation of funds and the 
dispersion of development, a database that tracks disasporic assistance in various regions, development needs within those regions, as well as the diasporic assistance received, would be a useful source for NGOs and District offices alike. This year, the District Secretariat of Jaffna has developed a report of over 600 pages titled, "Sustainable Development of Jaffna District - Five Year District Development Plan 2018-2022”, which is made available on the District Secretariat of Jaffna website (www.jaffna.dist.gov.lk) (District Secretariat of Jaffna, 2018).The Plan focuses on improving the geographical, social, economic, political and environmental conditions of the Sri Lankan state, while addressing the resettlement concerns of the island. Furthermore, it bridges discussions between local communities, stakeholders and all 15 divisional secretaries to identify their prioritized development needs within each respective sector, such as agriculture, healthcare, vocational training etc. Although this Plan appears to be quite sound on paper, it is the comprehensive implementation and productivity of this Plan that is to be tested. However, structured approaches to development work and plans, such as the aforementioned report, provide reliable and clear channels of engagement for diasporic youth to get involved in their homeland affairs.

On the contrary, Manoranjan (2018) and Nandakumar (2018) believe that the nature of the Tamil struggle has changes and so has diasporic involvement; therefore, the Tamil diaspora does not need a single overarching organizational structure such as the LTTE to successfully implement sustainable change in Sri Lanka. Manoranjan (2018) adds:

"I think diversity in opinions is something that's very natural, and something that exists in every community, and I don't think the Tamil community needs to all speak with one voice. I think it's good to have a plurality of opinions, and I think in development too, it's sort of specific and contextual, like what one village needs is not necessarily what another village needs. So, I don't think there should be a unity of approaches."

Nadesan (2018) corroborates Manoranjan's (2018) stance by conveying that although there should be an environmental scan of current stakeholders involved in charity and development 
work in Sri Lanka, "there is definitely value in having multiple ways of helping and multiple points of connecting...'Cause that's what any democratic society would have you do. There shouldn't be one gatekeeper, one way." Whether tunneled through a single source or by taking a multifaceted approach, the Tamil diaspora can influence their homeland through a variety of sources. Research findings merely suggest that a discrepancy exists between the diaspora and the homeland with regards to defining what a structured approach to engagement looks like. That said, this paper cannot determine which method of mobilization is more productive; however, if a diasporic member is interested in getting involved, there is a range of innovative and multifaceted ways to do so. This can be done through the various capacity-building methods discussed earlier, investments in certain industries to increase employment opportunities within the North and East, or by getting involved with think-tanks, research institutes and NGOs such as ACPR, PEARL, Comdu.it, Point Pedro Institute of Development, Tamil Guardian and more. Firstly, it is important to distinguish what professional assets a diasporic member may have that is most appropriate and fitting for the consulted needs of the group, team, individual, organization or industry, to begin the transference of such knowledge, material resources and social capital. Vimalarajah \& Cheran (2010) state that the Tamil diaspora is in fact a credible source for change; however, their capacity to mobilize is dependent on their ability to self-assess and acknowledge their strengths and weaknesses. By doing so, the productivity of diasporic engagement is augmented, and the various sectors of development are considered, given the advancement of the ever-growing professionally diverse Tamil diasporic community that exists on a global scale (Vimalarajah \& Cheran, 2010, p. 4). With that said, it is imperative to note that it is also up to the state to provide a foundation for such change to prosper in the post-war environment. For example, the education, healthcare and employment sectors of Sri Lanka need 
a base that can eventually be cultivated; however, there needs to democratic structures in place for civic participation. The state is resultantly responsible for establishing public institutions, but also for maintaining state accountability for mass atrocities as part of the transitional justice framework and to foster positive-peacebuilding (Subotic, 2011). The Tamil diaspora's involvement cannot be the only source of support for the Tamil community in Sri Lanka, as productive post-war state growth must be a conjoined effort between both state actors and diasporic activists. The reality is that the global Tamil diaspora can only put pressure on the Sri Lankan state and the international community to act against injustices committed by the sitting administration. Therefore, whether structured or not, the diaspora remains limited in its ability to produce large-scale policy changes and transform the political climate of the state in its entirety; nonetheless, every diasporic endeavour contributes to the rebinding of the social fabric of the state, that advances post-war sustainable development discourse, work and ideas.

\section{How Displacement Deters Positive Peace}

The exploitation of the internally displaced Tamil body in addition to the militarization of the state deprives post-war Sri Lanka of positive peacebuilding. Furthermore, Sinhala-Buddhist hegemony plays a role in the oppression and continued internal displacement of Tamils, the unrequited disappearances of family members as well the military occupation of Tamil land. Both research participants that identified as government officials discussed the importance of addressing resettlement issues before ensuing capacity-building ventures. Every single key informant mentioned that the resettlement of Tamil civilians remains a pressing concern. The Sirisena government has promised to return seized land, but these promises have yet to be kept (Tamil Guardian, 2018a). A clear example of this is the case of Iranaitivu, a region located in the Northern Province of Sri Lanka, where the Sri Lankan Navy has forcefully maintained their 
presence on Tamil lands regardless of resettlement promises (Tamil Guardian, 2018c). That said, some lands under military control have been released to families in Jaffna, Kilinochchi, Mullaitivu and Batticaloa and the UK has stepped forward with $£ 1$ million in funding to assist in the resettlement of these families. According to a statement made by the UK government, this funding is expected to go towards the reconstruction of road, sanitary services, local government services and civil society organizations, small business management, and agricultural equipment (Tamil Guardian, 2018g). "We [the UK government] will continue to encourage the Sri Lankan Government to make progress delivering their Human Rights Council commitments, and I hope that the UK's Sri Lankan diaspora will also play their part in encouraging that progress" (Tamil Guardian, 2018f). Nicholaspillai (2018), the Director of Planning of the District Secretariat of Jaffna, stated that "there are still welfare camps and approximately 649 families still live in those welfare camps in Tellippalai," a small town in the northern Jaffna. "We still need 28,800 amount of houses. 11,000 people are still residing at their friends and relatives' homes - co-living. We have to address their needs and create infrastructure facilities prior to discussing particular development goals. Right now, these are the immediate needs", she added. Initially created during the final stages of the war, "welfare camps" and/or "welfare villages" in Sri Lanka are essentially detention centres to house internally displaced persons. These camps were created by the Sri Lankan government and continue to be controlled by the military (Ramesh, 2009). According to the Sustainable Development of Jaffna District - Five Year District Development Plan 2018-2022, an outlined goal for resettlement is as follows: "Internally displaced persons (IDPs) and refugee returnees [are] to be resettled in their original land and resettled" (District Secretariat of Jaffna, 2018, p. 3) and the indicator of this goal is for all IDP welfare camps to be closed and no more refugees to resettle (District Secretariat of Jaffna, 2018, p. 3). For there to be 
positive peace, the concern of resettlement must be resolved by the state. In this case, the Tamil diaspora can make an influence by putting pressure on the Sri Lankan state to take accountability and the international community to intervene and assist in the rebuilding of the local Tamil community's livelihood. State accountability is imperative to resolve the issue of internal displacement; therefore, the heightened militarization and military occupation of lands cannot go unquestioned.

According to Price (2010), the existing link between positive peacebuilding and internal displacement must be explored. Price (2010) suggests that peace has several definitions; however, in the context of Sri Lanka, peace is defined by the government in relation to the "territorial unity of the unity of the state, where the LTTE have fought for a peace in regard to justice, achieved through self-determination" (p. 530). To have positive peacebuilding integrated into a post-conflict society, internal displacement must be resolved (Price, 2010). Therefore, the return of internally displaced Tamils (IDTs) within peace processes in Sri Lanka is imperative for the social, political and economic progression of the state. The United Nations Department of Economic and Social Affairs (UN DESA) (2008) discuss the importance of rebuilding trust between civilians and the government as an imperative step during the war-to-peace transitions. Furthermore, for positive peacebuilding to be efficiently implemented the return of IDTs to their respective homes in the North and East must be integrated into the entire recovery process and the state must address the underlying causes for their continued displacement nine years after the war's conclusion. According to Price (2010), positive peacebuilding goes beyond peace agreements and into the responsibility of the state. The primary objective of positive peace is relationship rebuilding between the state and its people as the IDPs of the country remain to be a part of the most marginal groups in Sri Lanka (Tamil and Muslim populations). Thus, the 
positive peacebuilding process is reliant on addressing the root causes of conflict, the physical security of civilians and the rebuilding of relationships and trust between civilians and the state. When IDTs return home or relocate outside of camps in the North, then that is when the relationship between the state and its minority civilians will improve. These conflict-affected areas must not be paraded as victory grounds or military zones but should be identified as land, homes and lives lost by Tamil civilians. Until the Tamil community is rightfully included and consulted in the post-conflict settlement planning process, it is very difficult to promote a national vision for a peaceful society. The longer Tamils are internally displaced, the higher the chances of a re-insurgence of violence and warfare. Although easier said than done, Jegannathan (2013) proposes that this post-LTTE era should be regarded as a new space for Tamils to merge and vocalize their mistrust and frustration in the Sri Lankan government (p. 5). The successful execution of establishing such a space is yet to be discovered as Tamils in Sri Lanka continue to lack representation in their own fight and even in their own state's development. Unfortunately, Sinhala-Buddhist hegemony has been woven right back into political reforms yet again. For capacity-building and positive peacebuilding processes to succeed in the post-war environment, seized lands must be returned to local communities and the resettlement livelihood concerns of those lands, such as the demolition of homes and sanitary services must be revitalized. The Tamil diaspora can influence these efforts through reports that advice political reform, rehabilitative services and through infrastructural development, but without state accountability and the enforced release of lands by the Sirisena administration, it is very difficult for Tamil civilians to focus on sustainable development opportunities without a roof over their heads. Moreover, the diaspora remains a stakeholder in homeland affairs, but they do not hold the same 
power as the government and/or military; therefore, their work is reactionary to state conditions and sitting administrative decisions.

\section{Intersectional Perspectives to Development and Diasporic Engagement}

A concept that is often lacking amid decision-making circles as well as this research study is the advantage of employing an intersectional approach to development discourse. Intersectionality through a development and diasporic engagement framework requires the consideration of several identity categories - such as gender, race (even shade of skin-tone, as it presents different advantages in various societies), age, sexuality, functional diversity, social class, etc. - within the presented structural struggles for equality in the post-war environment. According to Crenshaw (1991), the complexities of identity politics lies in the ignorance of intragroup differences that essentially shape the dimensions of the respective identity, such as class, gender, religious views, etc. Rather, "ignoring difference within groups contributes to tension among groups" (Crenshaw, 1991, p. 1242). In the contemporary, socially-progressive world, to truly assist the Tamil community in its entirety, politicized violence against women, mental health concerns within the LGBTI (Lesbian, Gay, Bisexual, Transgender or Intersex) community, religious divisions such as tensions within the Muslim community in Sri Lanka and many other intersectional issues must all be included in post-war development endeavours. Although this may be a Westernized approach to development, such discussions and involvement of Tamils from these varying sectors of the Tamil community will establish an allencompassing approach to mobilization efforts and can deeply influence the social conditions of the state by helping the hidden margins of society. Assistance for women-headed households was identified as a primary concern by the government officials interviewed in this study as well as Jenakumar (2018); however, the gender binary and gender roles were embedded within the discussion of the dispersal of development aid such as working in garment factories and 
receiving funding for sewing machines. The gendered nature of development aid is a research study in of itself; however, as a researcher, it is imperative to recognize that the lack of intersectionality within development discourse, when engaging in dialogue about diasporic mobilization, is in fact a limitation to this study. Unfortunately, there is a lack of research on the LGBTI community in Sri Lanka and many other non-Western states, which is why research and advocacy schemes of local civil society organizations and diasporic NGOs arguably have a responsibility to be inclusive of these populations. Acknowledging these vulnerable sectors of society will better inform the development needs of each community and therefore, these communities too should be consulted and included in conversations concerning the post-war sustainable development of Sri Lanka.

\section{$\underline{\text { DISCUSSION }}$}

As found by the growing involvement of diasporic organizations in post-war Sri Lanka, my research findings suggest that the work and perceptions of these particular key informants and their affiliated organizations are reflective of the present ground realities in their homeland. However, this does not suggest that the above statement is inclusive of the global Tamil diaspora in its entirety. There is a gap between diasporic members that are deeply involved through accredited organizations such as ACPR, PEARL, and Tamil Guardian; those who embrace their Tamil heritage but are not necessarily involved in post-development efforts; and those who do not immerse themselves in post-development efforts in Sri Lanka or their Tamil heritage. It became apparent during the interviews that many members from ACPR, PEARL and Tamil Guardian are vocationally affiliated; therefore, it arguably is an inner-circle kind of network. Because it is easier to retain and much harder to conceal the ground realities of their homeland 
through the widespread use of cellular devices, Internet technology, and social media platforms which are considered contemporary news outlets - the global Tamil diaspora is more aware of such realities if exposed to such information. However, unless diasporic members follow daily news outlets, such as Tamil Guardian, return to their homeland and/or are involved with NGOs conducting work on the ground, it is difficult to vastly submit that the perceptions of the global SLT diaspora is conclusively and accurately reflective of the ground realities in Sri Lanka.

Secondly, the findings suggest that the Tamil diaspora has the ability to influence their homeland with regards to social, economic and political outcomes favourable to Tamil civilians in Sri Lanka, while assisting the latter with post-war resettlement. Through advocacy, research, civil society capacity building projects, and other sustainable development efforts, the global SLT diaspora has been assisting the Tamil community in Sri Lanka. However, the institutional and ideological infiltration of militarization and Sinhala-Buddhist hegemony remains an obtrusive obstacle to diasporic involvement. This is where the state must take responsibility for its human rights violations and fashion an environment that warrants positive peace developments. Rather, key informants have found there to be a lack of trust and growth of fear between civilians and governing bodies, which has perpetually encouraged diasporic members to find trusted sources outside the administrative body to fuel fiscal and social support.

Moreover, this paper became an exploratory review of the major ongoing methods of diasporic mobilization, which have largely been encouraged through not-for-profit streams. By establishing recognized, multigenerational and diverse courses of engagement, diasporic members have an array of structured and well-developed options to get involved through NGOs, research think-tanks, the Toronto-Jaffna partnership, etc. Diasporic members do not need to "reinvent the wheel," and instead, can inclusively join together and build upon the ongoing 
efforts currently taking place. That said, the findings of this study have reviewed and disclosed ongoing and new avenues for diasporic mobilization, while acknowledging the complex interpretations of the Tamil identity that are interdependent for the maintenance of the Tamil consciousness.

In conducting the literature review, it became quite apparent that there is a richness of research on the complex and fluid nature of the Tamil identity, especially with regards to the second-generation Tamil populace. There is also a diverse array of literature investigating the relationship between the Tamil identity and the attachment it draws to the Tamil homeland, as well as a plethora of research regarding the ethno-nationalist war. However, there remains an insufficient quantity of academic literature on the contemporary post-war development efforts of the global Tamil diaspora. Additionally, there is no database that tracks the ongoing diasporic development projects in Sri Lanka, which makes it difficult to find areas of development that have yet to be exclusively addressed. As mentioned in the Limitations section, the lack of the civilian voice in this study as well as the lack of academic sources on the non-institutionalized civilian perspective truly impedes on the conclusiveness of the findings. That said, a review of diasporic mobilization initiatives is important to ensure the productive allocation of fiscal, academic, industrial, social and, economic resources provided by diasporic members. Thus, this paper strives to uncover an innovative pathway to discover new empirical research on this subject matter. 


\section{CONCLUSION}

In sum, the military defeat of the LTTE in May 2009 resulted in the end of the war, but also the beginning of a new era of negative peace, as the promotion of the closing stages of the protracted conflict had been joyously paraded by the state, while post-conflict settlement efforts have been halted or simply nonexistent. Additionally, this negative peace has further marginalized minority communities in Sri Lanka and generated a culture of militarism across the island. The triumph of the Sri Lankan armed forces has provided prevalent support for the Sinhalese-led Sirisena government and fellow Sinhalese comrades; but, Tamils have not been able to reap the same rewards. Furthermore, the sitting president Maithripala Sirisena has been making promises on the implementation of "thorough reform", however, they are similar to the neglected promises he made during his election campaign prior to getting his position as President. Some of these promises include decentralizing power to regional governments, pursuing the cases of those who disappeared during the Rajapaksa regime, and reforming the constitution to ensure no president could amass the power of his predecessor (Safi \& Perera, 2018). Aside from such promises, there continues to be many displaced persons primarily of Tamil origin. This study has explored the changing nature of the global Tamil diaspora and its involvement in post-war resettlement and sustainable development efforts, involving accumulated data informed by key Tamil actors and organizations. Moreover, this paper attempts to identify and prove the various structural barriers that exist, such as militarization and SinhalaBuddhist hegemony, in order to begin the positive peacebuilding process. Additionally, resolving internal displacement has surfaced as being central to the positive peacebuilding process. Seoighe (2011) states that "post-war, the Tamil narrative has been suppressed, manipulated and appropriated by different stakeholders - the government and state media, politicians, Tamil 
diaspora groups and international human rights organizations - whilst the people themselves are 'voiceless"' (p. 361). As identified in the Limitations section, the lack of a Tamil civilian voice in this paper is a shortcoming; however, the key informants of this study provided a review of the contemporary diasporic activities in Sri Lanka by discussing the ongoing projects that are taking place to contribute to the sustainable development of the state.

Through the new digitized de-territorialized space, the transnational Tamil diasporic community has been reflective of the present ground realities in their homeland, as it has become difficult to conceal the post-war conditions of the Sri Lankan state. Through reliable reporting sources such as Tamil Guardian as well social media platforms used by diasporic members and Tamil civilians in Sri Lanka, up-to-date data on the conditions of the Sri Lankan state are being disseminated and the Tamil perspectives on various national and international issues are being heard by a wider audience. It is also through this space, in addition to the physical environment, that the Tamil consciousness and the divergent interpretations of memory are continuously reproduced. There continues to be a disparity between the organizational structures of diasporic engagement; however, a linear or non-linear approach is immaterial to the fact that the state must take responsibility for providing a foundation for which assistance can be built upon. However, with a strong base and the implementation of civil society capacity-building programs using a network of Tamil professionals, the diaspora can influence the Sri Lankan state favourably with regards to social, economic and political outcomes for the Tamil civilians in Sri Lanka while assisting the latter with post-war resettlement. That said, the current efforts of ACPR, PEARL, Tamil Guardian, Comdu.it, UNDP, PPID and many other organizations should not go unnoticed. Overall, the accumulation of diasporic advocacy and activism schemes across diverse fields channels and influences postbellum Sri Lanka. This is achieved through research publications, 
media capacity-building programs for journalists, policy reform, lobbying, petitions and campaigns, pressurizing the international community, organized rallies, charitable efforts of donors, small business investments by diasporic members, and even through the informative Instagram, Twitter and Facebook posts shared across personal accounts amid the digitized Tamil transnational space. Diasporas are critical stakeholders in the post-war progression of Sri Lanka. The mere existence of these organizations that have informed this study provide a structure for the multi-generational involvement of diasporic Tamils for years to come and these channels provide easy and accessible methods for engagement. Although there may be many obstacles in attaining post-war sustainable development, through the interplay of state-actors, policy-makers, diaspora organizations, human rights activists and even private development schemes affirmative change can adapt from a wishful thought to a visible reality that can birth a true democratic nation and thus, maintain a peaceful Sri Lanka for future generations. 


\section{Appendix}

\section{RYERSONUNIVERSITY}

\section{Ryerson University \\ Consent Agreement}

You are being invited to participate in a research study. Please read this consent form so that you understand what your participation will involve. Before you consent to participate, please ask any questions to be sure you understand what your participation will involve.

\section{DIASPORIC MOBILIZATION AND POST-WAR UPLIFT: AN INQUIRY INTO THE GLOBAL SRI LANKAN TAMIL DIASPORA'S INFLUENCE IN POST-WAR SRI LANKA}

INVESTIGATORS: This research study is being conducted by the principal investigator, Sinthu Vimaladasan, a graduate student from the Immigration and Settlement Studies program, and her supervisor, Dr. Tariq Amin-Khan from the Department of Politics and Public Administration at Ryerson University.

If you have any questions or concerns about the research, please feel free to contact Sinthu Vimaladasan by phone at (647) 786 - 6043 and/or by e-mail at svimaladasan@ryerson.ca.

PURPOSE OF THE STUDY: First and foremost, a "diaspora" is a type of transnational community that has been dispersed from their homeland, whose members permanently reside in one or more 'host' countries (countries outside the homeland), and possess a collective idea or sense of belonging of the homeland. This study will explore ways in which the Tamil diaspora in Canada can play a constructive role in facilitating sustainable and diplomatic solutions to the post-war settlement and social development of Tamils in Sri Lanka. The Tamil diaspora is seen as a critical stakeholder in the post-war progression of Sri Lanka. The aim of this "new model of mobilization" is to discover how Tamils in Canada can be a part of post-war development efforts that foster self-sufficient Tamil communities in Sri Lanka.

A maximum of eleven key informants will be recruited for this study. The Tamil identity is comprised of various nationalities and ethnicities. With this in mind, all prospective participants must identify as Tamils with ancestral roots to Sri Lanka. Secondly, you must be a key informant who is well-established within the global Tamil community to some degree. As a key informant, you must represent an organization, institution, forum or council. Key informants for this research study include University Professors, Community Leaders in Sri Lanka, Research Directors, Board members, Senior Researchers, Executive Directors, City Councilors, Founders and other heads of organizations, who play a key role in ongoing post-war development initiatives in Sri Lanka. These key informants must also have first-hand knowledge about what is going on within the Tamil community in the diaspora and in the homeland of Sri Lanka. Thirdly, 
you must be above the age of 18; however, there will be no restrictions on your gender. A strict exclusion criterion is that you cannot be internally displaced in Sri Lanka or have recognized affiliations with the Liberation Tiger of Tamil Eelam (LTTE), as this may compromise your privacy and confidentiality, jeopardize the research study and your safety as well as the safety of the investigator.

As the principal investigator, I will be conducting this research in partial completion of my Masters of Arts degree in Immigration and Settlement Studies at Ryerson University. The results of this research study will contribute to my Major Research Paper (MRP).

Once I have successfully completed my MRP, I will notify you via e-mail. If you are interested in receiving a PDF or hardcopy of this MRP, please e-mail me back at svimaladasan@ryerson.ca. Additionally, there is a possibility that my research findings from this study may be published in an academic journal. If this research is published, you will be notified by e-mail, and if you would like access to this publication, please e-mail me back requesting this.

WHAT PARTICIPATION MEANS: If you volunteer to participate in this study, you will be asked to do the following:

- Consent to be interviewed with the principal investigator regarding your involvement and your affiliated organization's involvement in post-war development efforts in Sri Lanka

- Answer approximately eleven open-ended questions (unless consent is withdrawn)

- Some of these interview questions include:

- What geographical regions of Sri Lanka need the most help?

- What service(s) (such as mental health, education, agricultural services, and institutionbuilding) in Sri Lanka need(s) the most attention?

- What area(s) of development (social, economic, political, etc.) is/are most important to you and your organization, and what development efforts are you taking on in Sri Lanka?

- Consent to having this interview audio-recorded, transcribed (type-written copy of spoken material) and analyzed

- Agree to be interviewed in an environment of your preference that guarantees aural and visual privacy, or alternatively, in a booked room provided by a university or public library closest to you

- Consent to the duration of the study, which will be a minimum of 30 to 45 minutes

- Consent to providing the principal investigator with personal and identifiable data such as your name, job title, name of affiliated organization, e-mail address and telephone number for possible follow-ups

- Allow research findings (i.e. collected interview data) to be used by the principal investigator in her Major Research Paper

- Agree to the possible distribution of the MRP to research participants after the completion of the research study

- Provide consent so the research findings can be made available to participants through e-mail and in PDF form

POTENTIAL BENEFITS: The potential benefits from my research include providing you and your affiliated organization with my research to contribute to your development initiatives in Sri Lanka. My research is a review and an inquiry into the current efforts of Tamil diasporic 
organizations in Canada and organization on the ground in Sri Lanka, which will hopefully be useful for future initiatives or research. This will also help reveal if organizations are attempting to tackle the same development issue in Sri Lanka or if they are systematically working on different issues to productively help the resettlement of Tamils in Sri Lanka. That being said, I cannot guarantee, however, that you will receive any benefits from participating in this study.

WHAT ARE THE POTENTIAL RISKS TO YOU AS A PARTICIPANT: Some of the potential risks include, but are not limited to, psychological and social risks. The psychological risks during my interview process may include feeling anxious, upset, uncomfortable, guilty or stressed. Additionally, the interview may surface traumatic experiences from the conflict in Sri Lanka. To mitigate these risks, I will make sure that the interview is taking place in the environment of your preference. My interview questions will be specific to development efforts and I will not directly ask you about your experiences of war, as I do not want you to feel uncomfortable or make you psychologically re-live the trauma. As a former Crisis Line and Support Worker for the Sexual Assault Centre of Brant, I have been given formal training on the effective use of tone of voice and body language, when dealing with cases of trauma. I have attached a separate document listing various mental health or ethno-specific community services to each participant's consent form that are location specific. I assure you that all my participants will be receiving this information; however, the choice to use these services are not mandatory, but voluntary and strictly up to you.

Due to your established status in the community and because you are representing an organization, fears of embarrassment by research findings may emerge in addition to the fear of obtaining a damaged reputation within the Tamil community in Canada or Sri Lanka. I also acknowledge that because you are a well-established member in the Tamil community in Canada, England or Sri Lanka, it is easier for your identity to be directly or inadvertently revealed. Unless you consent to be identified in my research, I will ensure that I use a pseudonym for you and your affiliated organization. In addition, other practices, such as changing your reported characteristics (such as your gender) can be utilized to conceal your identity and thereby maintain the confidentiality of the data you have provided. I may also consider using umbrella terms such as "organization, institution, council" to minimize the chances of the participant's affiliated organization being revealed. Furthermore, there may be a potential fear that you will be exposed to militant groups or State authorities who oppose your development initiatives, which may also evoke reservations of your potential loss of privacy and/or confidentiality. The reason I have chosen to interview well-established Tamil key informants, like yourself, who are considered "public figures," is because I want to alleviate as many of these social risks as possible. As a result, my position as a researcher is just to further understand what you are already doing; therefore, the fear of being exposed is slim because my research is interested in your ongoing efforts. Additionally, I assure you that I am not affiliated with any authority and your participation is strictly voluntary. You can withdraw during and after you participation; however, I must be notified one week following the interview if you would like to withdraw your interview data from the research study.

Furthermore, I will maintain confidentiality by ensuring your identity cannot be revealed in my research if requested. Data will be de-identified as soon as possible after collection and I will separate identifiable variables (i.e., create identity code, destroy raw data). I will keep a separate 
code book with code names. I will follow-up with you via e-mail or by phone (whichever is most convenient for you) in the event that I wish to clarify the use of a word, phrase, quote, concept, etc. Because of the personal nature of the questions asked, you may reflect on unpleasant memories while responding to an interview question. However, if you feel uncomfortable, you may skip answering a question or stop participation, either temporarily or permanently.

CONFIDENTIALITY: In the case that you do not wish to be identified in the research, then no identifying information will be included in the dissemination of the results. In order to secure your identity and collected data, data sets shall always be stored in a secure location and with password-protected access. Digital data will be stored in encrypted files on my personal laptop, while hardcopies will be kept in a locked cabinet in my home office, which only I have keyaccess to. Data will be transported from Sri Lanka to Canada on my personal laptop through the aforementioned encrypted files that only I have the password to. Physical data will be kept in a file in my laptop bag, which will be kept in my key-locked carry-on suitcase that only I have access to. Next, data will be de-identified as soon as possible after collection and I will separate identifiable variables (i.e., create identity code, destroy raw data). In order to preserve your confidentiality and the confidentiality of your respective organization, I will use pseudonyms upon request. In addition, other practices, such as changing your reported characteristics (such as your gender) can be utilized to conceal your identity and thereby maintain the confidentiality of the data provided by participants. You will also be audio-recorded; however, after the transcription process, if there are specific quotes to be used in the final MRP, then those quotes will be sent to you to be reviewed prior to being published in the MRP. If any concepts, words, phrases or quotes are used in the interview that are unclear to me, then I will contact you through e-mail or by phone, with the request to review the content before it is used in the study. Because I am the principal investigator in this project, I will have access to this research data. My supervisor, Dr. Tariq Amin-Khan will have access to the coded and de-identified data to guarantee and maintain the confidentiality of my participants. Digital data will be transported through a USB, which will be returned to me immediately. The data on this USB will also be destroyed after the research process is complete. Physical data will be transported through a folder in a closed bag that will be key-locked, in which case my supervisor only has access to such data while I am physically present. Lastly, all physical and digital data will be shredded/deleted three years after the completion of my MRP (September 2021). This three year period will be useful in the event that I choose to pursue doctoral studies in this area of research.

COSTS TO PARTICIPATION: I will reimburse you for local travel expenses, if necessary. These expenses will not exceed city transportation in Canada or Sri Lanka. Alternatively, if we cannot meet in-person, we will set up a phone or Skype interview, in which case reimbursement for local travel expenses will not be applicable.

VOLUNTARY PARTICIPATION AND WITHDRAWAL: Participation is entirely voluntary. You can stop participating at any time. You can choose whether to be in this study or not. You do not have to answer every question or complete all aspects of the research. You can withdraw your consent to participate before, during or after your participation. However, I must be informed within a one-week period from the day of the interview if you do not want me to include your interview in my research. This will give me enough time to edit my work and adjust my findings accordingly before the first draft of my MRP is due. Your refusal to participate will 
involve no penalty or risks in revealing personal identity. Any interview data or personal or identifiable data collected will also be immediately destroyed (digital filled deleted and hardcopies shredded) if the participants choose to withdraw during or after participation. Your choice of whether or not to participate will not influence your future relations with Ryerson University, investigator Sinthu Vimaladasan or supervisor Dr. Tariq Amin-Khan.

DATA DISSEMINATION: The research findings will be a part of principal investigator Sinthu Vimaladasan's final Major Research Paper for her Master of Arts in Immigration and Settlement Studies at Ryerson University. Furthermore, she may consider publishing her research or providing her research to the organizations, institutions, councils or forums that contributed to her research study. The collected data may or may not assist their ongoing or upcoming efforts.

QUESTIONS ABOUT THE STUDY: If you have any questions about the research now, please ask. If you have questions later about the research, you may contact:

Sinthu Vimaladasan, Principal Investigator Graduate student from Immigration \& Settlement Studies MA Program, Ryerson University Telephone number: (647) 786 - 6043 (Canadian number) or 752814512 (temporary Sri Lankan number from June $5^{\text {th }}$ to July $2^{\text {nd }}, 2018$ )

E-mail: svimaladasan@ryerson.ca

Dr. Tariq Amin-Khan, Supervisor

Department of Politics \& Public Administration, Ryerson University

Telephone number: (416) 979-5000 x 6169

E-mail: takhan@politics.ryerson.ca

This study has been reviewed by the Ryerson University Research Ethics Board. If you have questions regarding your rights as a participant in this study please contact:

Research Ethics Board

c/o Office of the Vice President, Research and Innovation

Ryerson University

350 Victoria Street

Toronto, ON M5B 2K3

416-979-5042

rebchair@ryerson.ca 


\section{DIASPORIC MOBILIZATION AND POST-WAR UPLIFT: AN INQUIRY INTO THE GLOBAL SRI LANKAN TAMIL DIASPORA'S INFLUENCE IN POST-WAR SRI LANKA}

\section{CONFIRMATION OF AGREEMENT:}

Your signature below indicates that you have read the information in this agreement and have had a chance to ask any questions you have about the study. Your signature also indicates that you agree to participate in the study and have been told that you can change your mind and withdraw your consent to participate at any time. You have been given a copy of this agreement. You have been told that by signing this consent agreement you are not giving up any of your legal rights.

Name of Participant (please print)

Signature of Participant

Date

I agree to be audio-recorded for the purposes of this study. I understand how these recordings will be stored and destroyed.

Signature of Participant

Date

Please check mark your preference:

I consent to have my personal identity and the name of my affiliated organization included in the final version of the principal investigator Sinthu Vimaladasan's MRP.

I do not consent to have my personal identity included in the final version of the principal investigator Sinthu Vimaladasan's MRP, but I consent to have the name of my affiliated organization included in the MRP.

I do not consent to have my personal identity and the name of my affiliated organization included in the final version of the principal investigator Sinthu Vimaladasan's MRP. Instead, I would like her to use pseudonyms.

Date 


\section{References}

Abramo, G., D’Angelo, C., \& Rosati, F. (2016). Gender bias in academic

recruitment. Scientometrics, 106(1), 119-141. doi:10.1007/s11192-015-1783-3

Adayaalam Centre for Policy Research (ACPR). (2018). Adayaalam Centre for Policy Research. Retrieved August 01, 2018, from http://adayaalam.org/

Adayaalam Centre for Policy Research (ACPR) and People for Equality and Relief in Lanka (PEARL). (2017). Normalising the Abnormal: The Militarisation of Mullaitivu (pp. 1-33, Rep.).

Alagarajah, A. (2018, June 21). Sustainable Development, Resettlement and Diasporic Engagement in Sri Lanka [Personal interview].

Amarasingam, A. (2015). Pain, pride, and politics: social movement activism and the Sri Lankan Tamil diaspora in Canada. Athens, GA: University of Georgia Press.

Amarsingam, A., Naganathan, G., \& Hyndman, J. (2016). Canadian multiculturalism as banal nationalism: Understanding everyday meanings among Sri Lankan tamils in Toronto. Canadian Ethnic Studies, 48(2), 119-141. Retrieved from http://resolver.scholarsportal.info/resolve/00083496/v48i0002/119_cmabnuasltit

Anonymous. (2018, June 13). Sustainable Development, Resettlement and Diasporic Engagement in Sri Lanka [Personal interview].

Atputharajah, A. (2016). Hybridity and integration: A look at the second-generation of the sri lankan tamil diaspora in toronto

Azmin, A. (2018, June 22). Sustainable Development, Resettlement and Diasporic Engagement in Sri Lanka [Personal interview].

Bandaralage, J. S. (2009). The erosion of social capital in sri lanka. South Asia: Journal of South Asian Studies, 32(1), 110-135. doi:10.1080/00856400802709300

BBC. (2015, January 09). Q\&A: Post-war Sri Lanka. Retrieved November 12, 2017, from http://www.bbc.com/news/world-south-asia-11393458

BBC. (2017, September 04). Sri Lanka country profile. Retrieved November 12, 2017, from http://www.bbc.com/news/world-south-asia-11999611

Biernacki, P., \& Waldorf, D. (1981). Snowball sampling: Problems and techniques of chain referral sampling. Sociological methods \& research, 10(2), 141-163.

Bjarnegård, E., \& Melander, E. (2011). Disentangling gender, peace and democratization: The negative effects of militarized masculinity. Journal of Gender Studies, 20(2), 139-154. 
Brinkerhoff, J. M. (2009). Digital diasporas: Identity and transnational engagement. Cambridge: Cambridge University Press.

Burgio, G. (2016). When interculturality faces a diaspora. the transnational tamil identity. Encyclopaideia, 20(44) doi:10.6092/issn.1825-8670/5992

Canagarajah, S. (2013). Reconstructing heritage language: Resolving dilemmas in language maintenance for sri lankan tamil migrants. International Journal of the Sociology of Language, 2013(222), 131-155. doi:10.1515/ijsl-2013-0035

CBC News. (2009, March 16). Toronto Tamils slow traffic in latest Sri Lanka protest | CBC News. Retrieved August 01, 2018, from https://www.cbc.ca/news/canada/toronto/toronto-tamils-slow-traffic-in-latest-sri-lankaprotest-1.863849

Cheran, R. 2007. Transnationalism, Development and Social Capital: Tamil Community Networks in Canada, in: Luin Goldring and Sailajah Krishnamurti (eds.). Organizing the Transnational: Experiences of Asian and Latin American Migrants in Canada. Vancouver: UBC Press, 277-305.

City of Toronto (2017). India and Sri Lanka Business Mission 2017 - Report for Action. Retrieved March 15, 2018, from https://www.toronto.ca/legdocs/mmis/2017/ed/bgrd/backgroundfile-106663.pdf

Clavin, P. (2005). Defining transnationalism. Contemporary European History, 14(4), 421-439. doi:10.1017/S0960777305002705LINKS

Cohen, R. (1997). Global Diasporas: An Introduction (2nd ed.). London: UCL Press.

Comdu.it. (2018). Comdu.it: Partnering people projects. Retrieved July 31, 2018, from http://comdu.it/about-us/

Crenshaw, K. (1991). Mapping the margins: Intersectionality, identity politics, and violence against women of color. Stanford Law Review, 43(6), 1241-1299. doi:10.2307/1229039

Creswell, John W., and Cheryl N. Poth. (2018). Qualitative Inquiry and Research Design: Choosing Among Five approaches. Thousand Oaks, CA: Sage. (pp. 65-110).

De Mel, N. (2009). Gendering the new security paradigm in sri lanka. IDS Bulletin, 40(2), 36-43. doi:10.1111/j.1759-5436.2009.00020.x

District Secretariat - Jaffna. (n.d.). Planning Secretariat. Retrieved July 10, 2018, from http://www.jaffna.dist.gov.lk/index.php?option=com_content\&view=article\&id=83\&Ite mid=208\&lang=en 
District Secretariat of Jaffna. (2018). The Sustainable Development of Jaffna District - Five Year District Development Plan 2018-2022(Sri Lanka, District Secretariat of Jaffna). Retrieved August 15, 2018.

Dyrstad, K. (2012). After ethnic civil war: Ethno-nationalism in the Western Balkans. Journal of Peace Research, 49(6), 817-831.

Frayn, A., \& Phillips, T. (2018). Introduction: War and memory. Journal of War \& Culture Studies, 11(3), 181-191. doi:10.1080/17526272.2018.1490075

Gaul, A. (2017). Security, sovereignty, Patriotism - Sinhalese nationalism and the state in sri lankan history textbooks. Ethnopolitics, 16(2), 161-178.

doi:10.1080/17449057.2015.1041834

Goodhand, J. (2010). Stabilising a victor's peace? humanitarian action and reconstruction in eastern sri lanka. Disasters, 34(s3), S342-S367. doi:10.1111/j.1467-7717.2010.01212.x

Goodhand, J. (2012). Sri lanka in 2011: Consolidation and militarization of the post-war regime. Asian Survey, 52(1), 130-137. doi:10.1525/as.2012.52.1.130

Grant, C., \& Osanloo, A. (2014). Understanding, Selecting, and Integrating a Theoretical Framework in Dissertation Research: Creating The Blueprint for Your "House". Administrative Issues Journal: Connection Education, Practice and Research,4(2), 12-26. doi:10.5929/2014.4.2.9

Guribye, E., \& Tharmalingam, S. (2017). Tamil diaspora-driven development aid: Towards an understanding of context, networks and historical changes. Forum for Development Studies, 44(2), 171-188. doi:10.1080/08039410.2016.1273849

Harrison, F. (2013, November 15). Who is Mahinda Rajapaksa? Hero or war criminal? Sri Lankan leader. Retrieved August 15, 2018, from https://www.independent.co.uk/news/world/asia/hero-or-war-criminal-sri-lankan-leadermahinda-rajapaksa-under-pressure-8940591.html

Herath, S. (2015). Language policy, ethnic tensions and linguistic rights in post war sri lanka. Language Policy, 14(3), 245-261. doi:10.1007/s10993-014-9339-6

Huddy, L. (2001). From social to political identity: A critical examination of social identity theory. Political psychology, 22(1), 127-156.

Human Rights Council. (2017, February 10). Report of the Office of the United Nations High Commissioner for Human Rights on Sri Lanka. Sri Lanka, Colombo.

Human Rights Watch. (2012, November 14). UN: Act on Failings in Sri Lanka. Retrieved November 12, 2017, from https://www.hrw.org/news/2012/11/14/un-act-failings-srilanka 
Human Rights Watch. (2017, January 12). Sri Lanka. Retrieved November 8, 2017, from https://www.hrw.org/world-report/2017/country-chapters/sri-lanka

Hyndman, J., \& Amarasingam, A. (2014). Touring "Terrorism": Landscapes of memory in Post-War sri lanka. Geography Compass, 8(8), 560-575. doi:10.1111/gec3.12149

International Committee of the Red Cross (ICRC). (2018). Proportionality. Retrieved August 01, 2018, from https://casebook.icrc.org/glossary/proportionality

Jegannathan, J. (2013). Social Media: Sri Lanka's New War Zone(pp. 1-6, Issue brief No. 226). Institute of Peace and Conflict Studies. Retrieved July 31, 2018, from http://www.ipcs.org/issue_briefs/issue_brief_pdf/IB226-Jegan-SriLankaSocialMedia.pdf

Jenakumar, R. (2018, June 20). Sustainable Development, Resettlement and Diasporic Engagement in Sri Lanka [Personal interview].

Kok, S., \& Rogers, R. (2017). Rethinking migration in the digital age: Transglocalization and the somali diaspora. Global Networks, 17(1), 23-46. doi:10.1111/glob.12127

Kumar, P. (2018). Rerouting the narrative: Mapping the online identity politics of the tamil and palestinian diaspora. Social Media + Society, 4(1), 205630511876442. doi:10.1177/2056305118764429

Lopez, K. A., \& Willis, D. G. (2004). Descriptive versus interpretive phenomenology: Their contributions to nursing knowledge. Qualitative Health Research, 14(5), 726-735. doi:10.1177/1049732304263638

Manoranjan, T. (2018, July 17). Sustainable Development, Resettlement and Diasporic Engagement in Sri Lanka [Personal interview].

Matua, G. A., \& Van Der Wal, Dirk Mostert. (2015). Differentiating between descriptive and interpretive phenomenological research approaches. Nurse Researcher, 22(6), 22-27. doi:10.7748/nr.22.6.22.e1344

Nadarajah, S., \& Sriskandarajah, D. (2005). Liberation struggle or terrorism? the politics of naming the ltte. Third World Quarterly, 26(1), 87-100. doi:10.1080/0143659042000322928

Nadesan, K. (2018, July 12). Sustainable Development, Resettlement and Diasporic Engagement in Sri Lanka [Personal interview].

Nandakumar, T. (2018, July 04). Sustainable Development, Resettlement and Diasporic Engagement in Sri Lanka [Online interview].

Nicholaspillai, S. (2018, June 13). Sustainable Development, Resettlement and Diasporic Engagement in Sri Lanka [Personal interview]. 
O’Neill, T. (2015). In the path of heroes: Second-generation tamil-canadians after the LTTE. Identities, 22(1), 124-139. doi:10.1080/1070289X.2014.931233

Oxford Dictionary. (2018). Militarism | Definition of militarism in English by Oxford Dictionaries. Retrieved August 20, 2018, from https://en.oxforddictionaries.com/definition/militarism

Pande, A. (2017). Role of diasporas in homeland conflicts, conflict resolution, and post-war reconstruction: The case of tamil diaspora and sri lanka. South Asian Diaspora, 9(1), 5166. doi:10.1080/19438192.2016.1236458

People for Equality and Relief in Lanka (PEARL). (n.d.). About Us. Retrieved July 10, 2018, from http://pearlaction.org/about-us/

Perera, A., \& Safi, M. (2018, April 10). Sri Lanka opens door for return of divisive former president. Retrieved April 12, 2018, from https://www.theguardian.com/world/2018/apr/10/sri-lanka-opens-door-for-return-ofdivisive-former-president-mahinda-rajapaksa

Pieris, A. (2014). Southern invasions: Post-war tourism in sri lanka. Postcolonial Studies, 17(3), 266-285. doi:10.1080/13688790.2014.987899

Point Pedro Institute of Development (PPID). (2018). About PPID. Retrieved July 31, 2018, from http://pointpedro.org/

Price, N. (2010). Integrating 'Return' with 'Recovery': Utilising the return process in the transition to positive peace: A case study of sri lanka. The Round Table, 99(410), 529545. doi:10.1080/00358533.2010.509948

Ramesh, R. (2009, February 12). Sri Lanka civil war refugees to be housed in 'welfare villages'. Retrieved August 15, 2018, from https://www.theguardian.com/world/2009/feb/12/srilanka-refugees-welfare-camps

Rampton, D. (2011). 'Deeper hegemony': The politics of sinhala nationalist authenticity and the failures of power-sharing in sri lanka. Commonwealth \& Comparative Politics, 49(2), 245-273. doi:10.1080/14662043.2011.564476

Rodriguez, S. M. (2018). Building civilian militarism: Colombia, internal war, and militarization in a mid-term perspective. Security Dialogue, 49(1-2), 109-122.

doi:10.1177/0967010617743201

Roy, S. (2015, March 16). In Sri Lanka, underworked army runs resorts, shops, salons and travel agencies. Retrieved August 1, 2018, from https://indianexpress.com/article/world/neighbours/in-sri-lanka-underworked-army-runsresorts-shops-salons-and-travel-agencies/ 
Sandercock, L., Dickout, L. and Winkler, T. (2004, May) The Quest for an Inclusive City: An Exploration of Sri Lankan Tamil Experience of Integration in Toronto and Vancouver, Research on Immigration and Integration in the Metropolis. Working Paper Series No. 04-12, Vancouver Centre for Excellence. 1-50.

Sarvananthan, M. (2016). Elusive economic peace dividend in sri lanka: All that glitters is not gold. GeoJournal, 81(4), 571-596. doi:10.1007/s10708-015-9637-3

Sarvananthan, M. (2018, June 15). Sustainable Development, Resettlement and Diasporic Engagement in Sri Lanka [Personal interview].

Satkunanathan, A. (2016). Collaboration, suspicion and traitors: An exploratory study of intracommunity relations in post-war northern sri lanka. Contemporary South Asia, 24(4), 416-428. doi:10.1080/09584935.2016.1252315

Seoighe, R. (2016a). Discourses of victimization in sri Lanka's civil war: Collective memory, legitimacy and agency. Social \& Legal Studies, 25(3), 355-380.

doi:10.1177/0964663915614097

Seoighe, R. (2016b). Nationalistic authorship and resistance in northeastern sri lanka. Society and Culture in South Asia, 2(1), 1-30. doi:10.1177/2393861715608971

Singh, H. (2008). ethnic identity consciousness in the developing countries : Indian experience. The Indian Journal of Political Science, 69(3), 493-504

Shan, N. (n.d.). Neethan Shan - City Councillor. Retrieved July 10, 2018, from http://councillorshan.ca/

Shan, N. (2018, July 08). Sustainable Development, Resettlement and Diasporic Engagement in Sri Lanka [Personal interview].

Smith, C. W. (2013). Ethnicity and the role of group consciousness: A comparison between african americans and black immigrants. Politics, Groups, and Identities, 1(2), 199-220. doi:10.1080/21565503.2013.786650

Somasundaram, D., \& Sivayokan, S. (2013). Rebuilding community resilience in a post-war context: Developing insight and recommendations - a qualitative study in northern sri lanka. International Journal of Mental Health Systems, 7, 3-3. doi:10.1186/1752-4458-73

Sriskandarajah, A. (2014). Demonstrating identities: Multiculturalism, citizenship, and tamil canadian identities. Diaspora: A Journal of Transnational Studies, 17(2), 172-195. Retrieved from http://resolver.scholarsportal.info/resolve/10442057/v17i0002/172_dimcatci

Sterland, B. (2006, June). Civil Society Capacity Building in Post-Conflict Societies: The 
Experience of Bosnia and Herzegovina and Kosovo. Retrieved March 03, 2018, from https://www.intrac.org/wpcms/wp-content/uploads/2016/09/Praxis-Paper-9-CivilSociety-Capacity-Building-in-Post-Conflict-Societies-Bill-Sterland.pdf

Stets, J. E., \& Burke, P. J. (2000). Identity theory and social identity theory. Social psychology quarterly, 224-237.

Subotic, J. (2011). Expanding the scope of post-conflict justice: Individual, state and societal responsibility for mass atrocity. Journal of Peace Research, 48(2), 157-169. doi:10.1177/0022343310394696

Tamil Guardian. (2017, August 12). Buddhas on the A9 - Sinhalisation of Vavuniya. Retrieved August 1, 2018, from https://www.tamilguardian.com/content/buddhas-a9-sinhalisationvavuniya

Tamil Guardian. (2018a, January 09). False Promises. Retrieved August 15, 2018, from https://www.tamilguardian.com/content/false-promises

Tamil Guardian. (2018b, March 01). Increasing militarisation: Sri Lankan Navy opens new buildings at Jaffna base. Retrieved August 01, 2018, from

https://www.tamilguardian.com/content/increasing-militarisation-sri-lankan-navy-opensnew-buildings-jaffna-base

Tamil Guardian. (2018c, May 15). Navy to remain on Iranaitivu, families promised resettlement. Retrieved August 15, 2018, from https://www.tamilguardian.com/content/navy-remainiranaitivu-families-promised-resettlement

Tamil Guardian. (2018d, July 18). 500 days of protest - Worldwide rallies supporting Tamil Families of. Retrieved July 31, 2018, from https://www.tamilguardian.com/content/500days-protest--worldwide-rallies-supporting-tamil-families-disappeared

Tamil Guardian. (2018e, July 26). Soldiers turned handymen: Sri Lanka's ongoing militarisation of Tamil. Retrieved August 1, 2018, from https://www.tamilguardian.com/content/soldiers-turned-handymen-sri-lanka's-ongoingmilitarisation-tamil-schools

Tamil Guardian. (2018f, July 27). Militarisation: Sri Lankan army involves itself in cleaning up a church. Retrieved August 1, 2018, from https://www.tamilguardian.com/content/militarisation-sri-lankan-army-involves-itselfcleaning-church

Tamil Guardian. (2018g, August 14). £1m UK funding for families resettling after military occupation in. Retrieved August 15, 2018, from https://www.tamilguardian.com/content/£1m-uk-funding-families-resettling-aftermilitary-occupation-north-east

Tapscott, R. (2018). Policing men: Militarised masculinity, youth livelihoods, and security in 
conflict-affected northern uganda. Disasters, 42(S1), S119-S139. doi:10.1111/disa.12274

Thanakumar, D. (2018, June 20). Sustainable Development, Resettlement and Diasporic Engagement in Sri Lanka [Personal interview].

Thiranagama, S. (2014). Making tigers from tamils: Long-Distance nationalism and sri lankan tamils in toronto. American Anthropologist, 116(2), 265-278. doi:10.1111/aman.12099

Thurairajah, K. (2017). The case of the sri lankan tamil diaspora and homeland: A shared ethnic identity? Studies in Ethnicity and Nationalism, 17(1), 115-132. doi:10.1111/sena.12222

United Nations Development Programme (UNDP). (2018a). Sustainable development. Retrieved July 10, 2018, from http://www.undp.org/content/undp/en/home/sustainabledevelopment.html

United Nations Development Programme (UNDP). (2018b). Sustainable Development Goals. Retrieved from http://www.undp.org/content/undp/en/home/sustainable-developmentgoals.html

United Nations Development Programme (UNDP) Sri Lanka. (2018). UNDP in Sri Lanka. Retrieved July 19, 2018, from http://www.lk.undp.org/

UN-Habitat. (2013). Women in Post-Conflict Settlement Planning (Vol. 978-92-1-132603-1). Nairobi: United Nations Human Settlements Programme. Retrieved April 12, 2018, from mirror.unhabitat.org/pmss/getElectronicVersion.aspx?nr=3553\&alt=1.

Vertovec, Steven. 2005. 'The Political Importance of Diasporas'. Centre on Migration, Policy and Society, Working Paper 13: 1-11.

Vimalarajah, L., \& Cheran, R. (2010). Empowering diasporas: The dynamics of post-war transnational Tamil politics.

Wayland, S. (2004). Ethnonationalist Networks and Transnational Opportunities: The Sri Lankan Tamil Diaspora. Review of International Studies, 30(3), 405-426.

Widger, T. (2016). Philanthronationalism: Junctures at the Business-Charity nexus in Post-war sri lanka. Development and Change, 47(1), 29-50. doi:10.1111/dech.12185

Woods, O. (2012). Sri lanka's informal religious economy: Evangelical competitiveness and buddhist hegemony in perspective. Journal for the Scientific Study of Religion, 51(2), 203-219. 10.1111/j.1468-5906.2012.01642.x

World Bank. (2011). Resources: Social Capital. Retrieved August 01, 2018, from http://www.worldbank.org/en/webarchives/archive?url=httpzzxxweb.worldbank.org/archi ve/website01360/WEB/0_MEN-2.HTM\&mdk=23354653

World Bank. (2018). Sri Lanka Overview: The World Bank In Sri Lanka. Retrieved August 15, 
2018, from http://www.worldbank.org/en/country/srilanka/overview\#3 